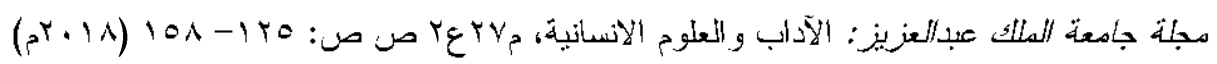
DOI:10.4197/Art.27-2.5

دور الر أسمال النوعي في تحديد الهوية المهنية للمر أة السعودية

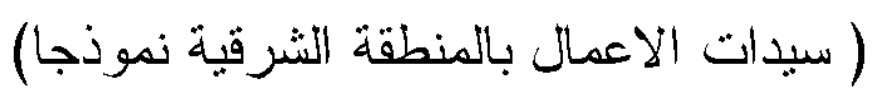

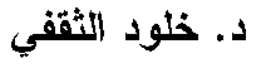

\section{استاذ مساعد جامعة الملك فيصل}

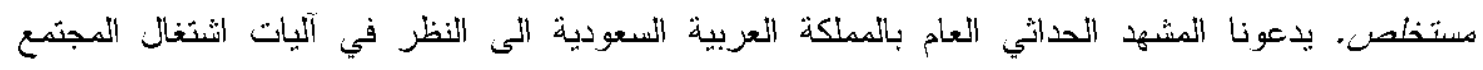

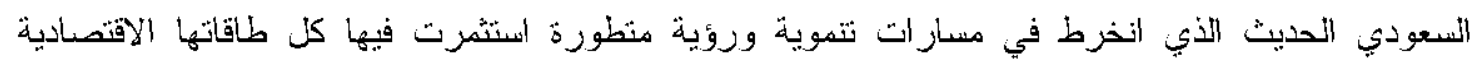

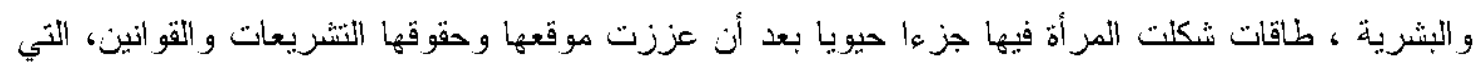

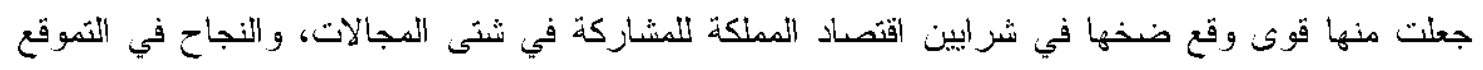

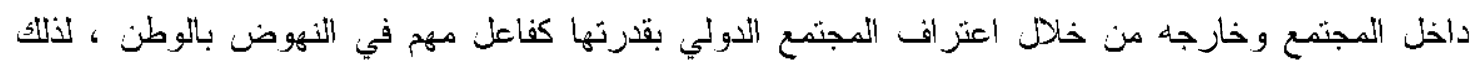

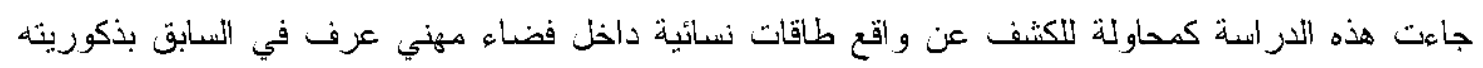

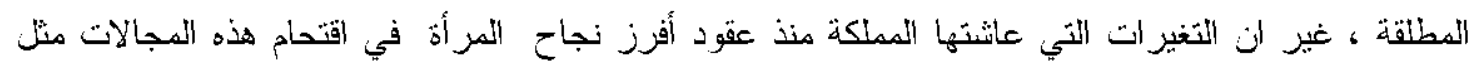

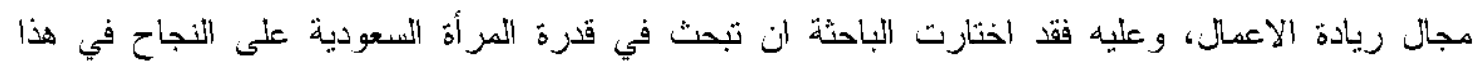

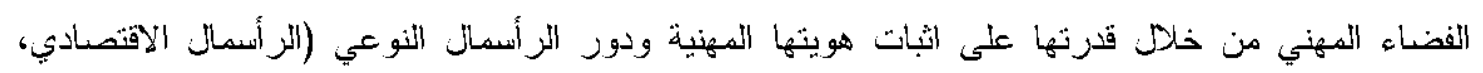

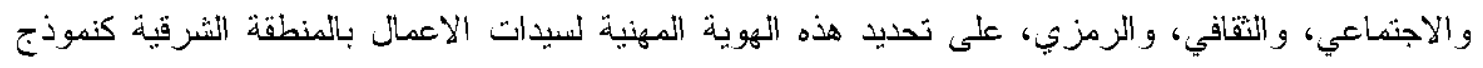
للار اسة).

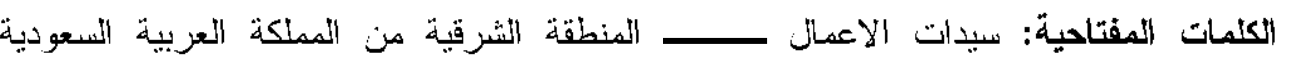

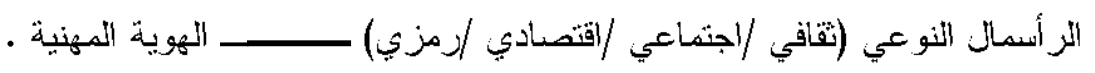

النظر في وضعية المرأة والعهل على الارتقاء

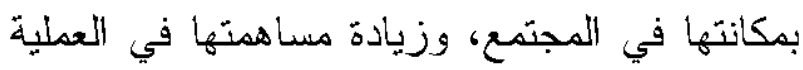
التتموية و السياسية و الاقتصادية و ولائية الاجنماعية، و العمل على تذليل الصعو بات التي تعتزض وض تقدمها. فقد أصدر مجلس الوزر اء قرارا وضح فيه سياسة

\section{إثكالية البحث}

ان الاتجاهات الحديثة للمملكة و التغير الجذري الأي عرفه المجتمع السعودي مع الانفتاح على الحداثنة

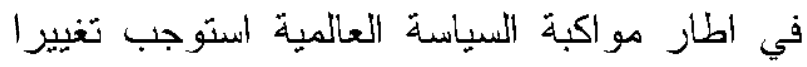

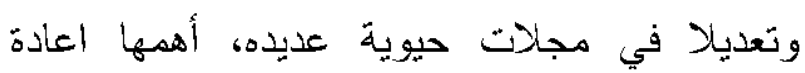


تشنكل وفقا للتغييزات الاجنماعية والثقافية و و العولمية، باعتبارها قد ساهمت في التعبير عن مجمو عه من السمات الخاصة بشخصية الإفراد و و تعبر عن الخصوصية و عن ثقافة المجتمع، ولغته و عقيدته وتاريخه، ونساهم في بناء جسور من التو اصل بين كافة الأفر اد سو اء داخل مجتمعهم أو وله

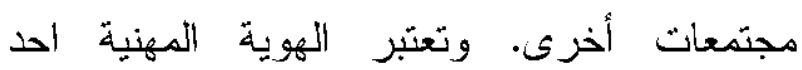
مركبات الهوية الذاتية او الشخصية، فالهوية المهنية تأخذ و تطرح وفق عمليه التواصل و التفاعل الاجنماعي، والتي تكون كذلك بفعل التتشئة الاجتماعية، وهي تثرجم كأفعال وسلوكيات تتجسد عبر ها الممارسة المهنية لذلك فهي في تفاعل مستير عبر الزمان و المكان قبل الدخول اللى عالم المؤسسة 'ب فالشعور بالهوية المهنية هو محصله للعلاقات التفاعلية المتطورة ضمن ميدان العمل بل كوبنائها يقوم على نوعين من المعاملات: الاول(تعامل موضوعي) من خلا الاخرين يعني

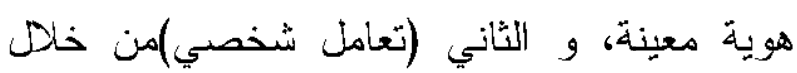

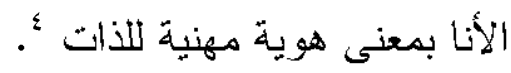
تصور دفع الباحثه القى المغامرة السوسيولوجية وطرح إثكالية الدراسة عن إنكالية دور الز أسمال النوعي في تحديد الكهوية المهنية لسيدات الاعمال السعوديات، ما دفعها الى تقصي هذا الدور من

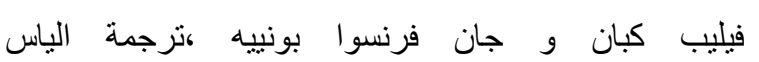

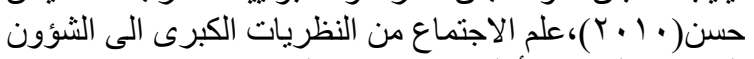

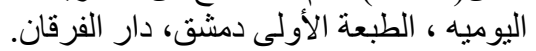

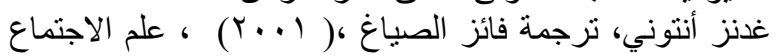

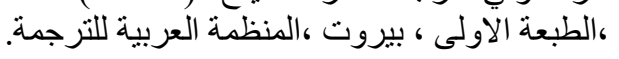

المملكة العربية السعودية اللهادفة التى اتاحه الفزصة للمر أة السعودية في التعليم ونحصيل أُعلى الارجات العلمية ، وفتح المجال أمامها في ميدان الععل لتولي مهام ومسؤوليات مختلفة، ومتذرجه إلى أعلى المستويات القيادية داخل المنظومة الادارية الحكومية ،وذللك وفق أحكام التشريعة الإسلامية، وكذلك توسيع مجالات عمل المرأة السعودية، وزيادة فرص ثوظيفها واصدار مجموعه من الانظمة و التشريعات بهذا الثأن' . فالديناميكية و التغير هما مرصد حركة الافراد داخل المجنمع لتطوره و تقدمه ، فالفرد لا يعيش وحيدا بل في جماعة يتفاعل معهم في اطنار شبكة علائقيه وأنشطه اجنماعيه تؤدي في النهاية إلى مجموعه من الأحداث و النتائج يطلق عليها ( التغير الاجنماعي ) - social change - و عالم الاجنماع جورج بالاندييه George Balandier لاحظ ان المجتمع طاقات ماديه و روحيه تتشأ عنها الضمائر الاجنماعية ،حيث درس علم اجنماع العلاقات بين هذه الطاقات وكيفيه تأثر ها بالنسق الاجتماعي، وتوصل القى ان هنالك ديناميكية اجناعيه، داخليه وخارجيه تعنمد على الثقافة و الوجدان و العاطفة و جميعها تؤثر في نسق وهوية المجتمع'· هوية يعتبر البحث فيها من المواضيع المتجددة، التي

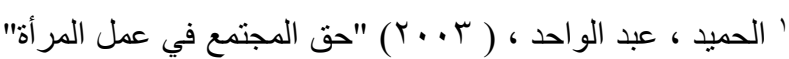

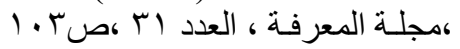

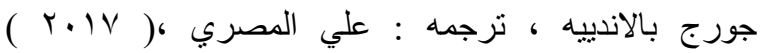

$$
\begin{aligned}
& \text { الانثروبولوجيا السياسيه ،الطبعة الثنانية، بيروت، المؤسيه } \\
& \text { الجامعيه للار اسات و النشر النش }
\end{aligned}
$$


أكسبها رأسمالا ثقافيا بفضي الى تكوين رساميل أخرى وهو ما جعل الباحثّة تتساعل في إثكالية البحث عن دور التر أسمال النوعي في تحديد الهوية

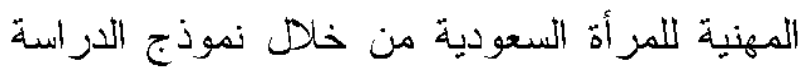
سيدات الاعمال بالمنطقة الشرقية؟ وكيف شكل الانتماء الطنقي و الجغز افي عاملا مهما في تموقع سيدة الاعمال داخل الفضاء المهني؟ وما هو تمنل

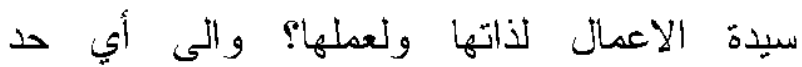
اسنطاعت ان تحقق لنفسها الرضا المهني؟ وهل

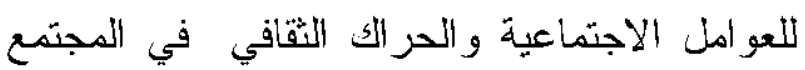
السعودي دور في تشكيل الهوية المهنية لسيدات

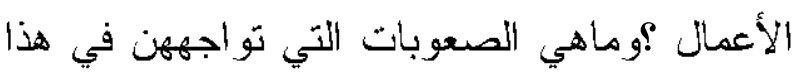

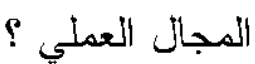
r- أهمية البحث العملي

تكمن أهمية هذه الاراسة في كونها تفتح وصيدا

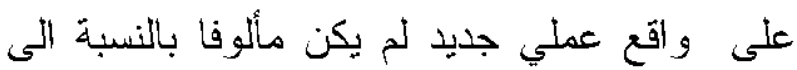

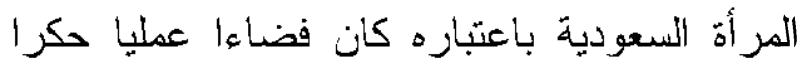

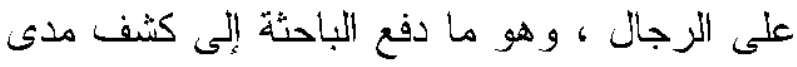

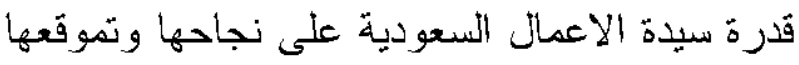
في هذا الحقل الأي ارتبط برساميل متتو عه منها ما

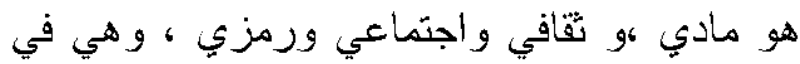
الحقيقة رساميل تعزز دخول المرأة لمجال ريادة الاعمال ونجاحها رغم الكثير من المعوقات

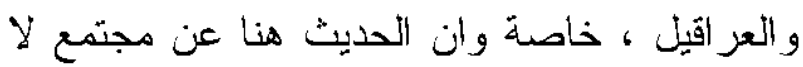
تزال يرسب في ذهنه مخيال اجتماعي وصورة

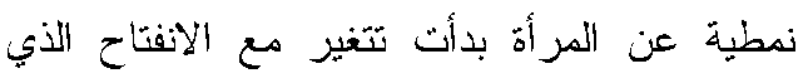

خلا البحث في الحرالك الاجنماعي و الثتقافي و السياسي والاقتصادي، الأي عرفه المجتمع السعودي والأي افضى التى تنغير في البنية الذهنية

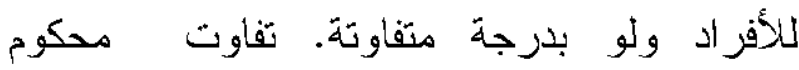
بمرجعيات وانتماءات مختلفة، تطرح بدورها تساؤلات حول امندادات وحدود قدرة المرأة السعودية على مجابهة المعوقات الاجتماعية و التقافية، ضمن مفارقات عديدة، منها محاو لات تخطي البنيه الذهنية التقليدية لتمثل دور المرأة

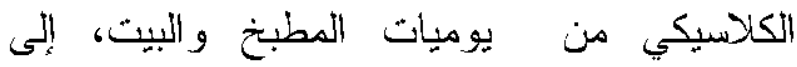
الانخر اط في المجالات العلمية و العملية وتقلدها المناصب خاصة مع الدفعة القوية لرؤية.r.r. و التي فتحت الباب على مصر اعيه لنجاحات رائده تسير على دربها المرأة السعودية بخطى ثنابتة، هيأت لها مسار ات تاريخية منتالية، بدءا من اتاحة الفزصة لها لتعزيز شخصيتها من خلال تمكينها من لهن لهن

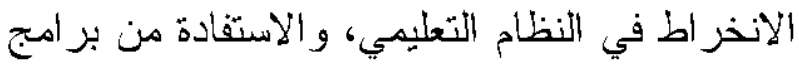
تتمية الموارد البشرية ،و التمكين الاقتصادي الذي يركز على التوسع في مجالات عمل المر أة، لتحقيق استقلاليتها وحصولها على دخل يضدن لها العيش الكريم، بالإضافة التى تمكينها من المشاركة الإيجابية في عملية صنع التزار، و الرففع من قدرتها على التحليل الموضو عي و النقد الو اعي. لقد شكلت كل هذه القزارات منعرجا حاسما في لي النهوض بو اقع المر أة السعودية و اخر اجها من طور

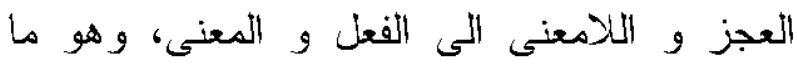


يعتبر المجنمع السعودي نموذجا حيا "للايناميكا الاجتماعية" الذي تحدث عنه جور ج بالندييه في علم الاجنماع الديناميكي، لما عرفته اللنى الاجنماعية

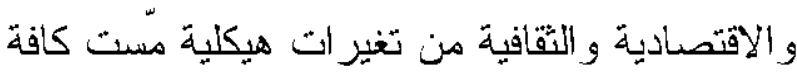

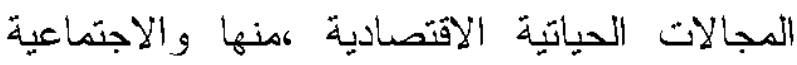
و الثقافية ،وانفتاح على العالم و السيرورة الحداثية

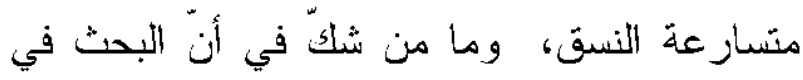

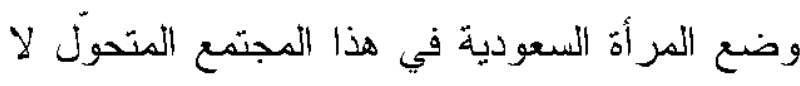
يمكن أن يستند إلى أحكام مسبقة أو نتائج حتمية،

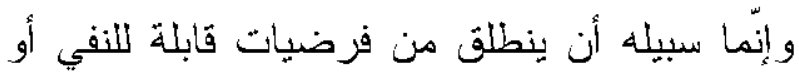

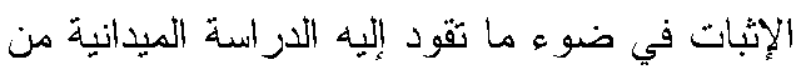

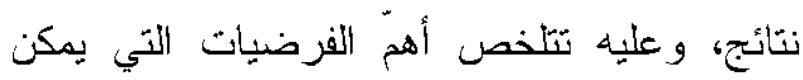

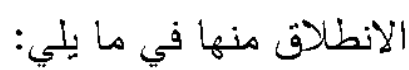

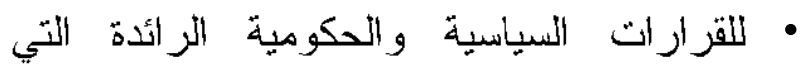

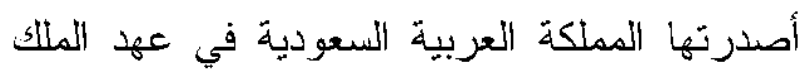
عبد الله - رحمه الله - وعهد الملك سلمان حفظه الله ورعاه - دور مهم في تحديث المجتمع،

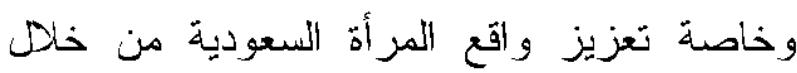
ادماجها في المسيرة التعلمية و العطلية

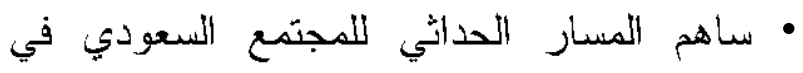
انخر اط المر أة السعودية في مجال ريادة الاعمال وساهم في تشكيل عدد لا بأس به من سيدات الأعمال. - الماه

ثلعب الز أسمال النوعي للمرأة السعودية دورا في تحديد تصور سيدة الاعمال لنفسها ولعمطها،

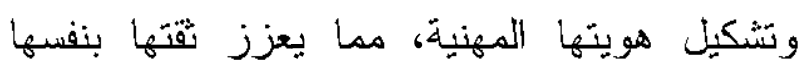

عرفته المملكة العربية السعودية والقوانين التي عززت مكانة المر أة وساعدتها على النجاح و التميز في مجالات مختلفة عملت الباحثة على كثف مجال حيوي من بينها وهو ريادة الاعمال كفضاء جديد

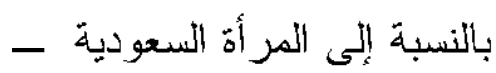

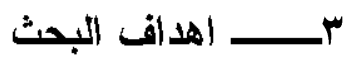
يرمي هذا البحث إلى أهداف عديده منها: القاء

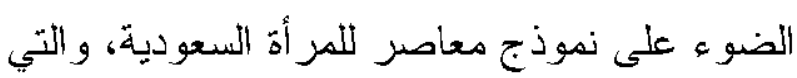

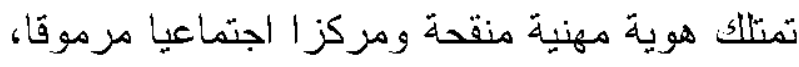
من خلا التعرف على مجموعه من سيدات الاعمال اللاتي قطعن شوطا من المثابرة و التميز

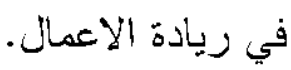
• محاولة تقصي دور الرأسمال النوعي في تحديد

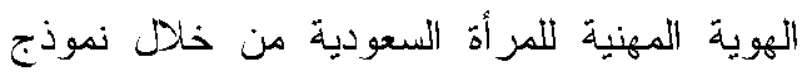

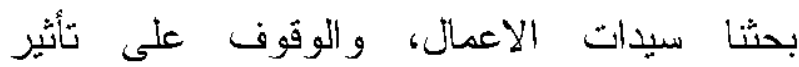

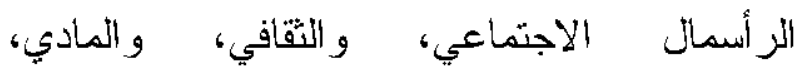
و الرمزي، على تموقعها ونجاحها في مجال ريادة الاعمال رغم وجود معوقات وصعوبات لا تزات لهمبات تو اجهها المر أة السعودية. •البحث في مركبات الهوية الشخصية، والهوية المهنية لسيدات الاعمال، ومدى قدرتهن على تحقيق الامن المهني داخل حقل بتميز بتراتبية وصراع

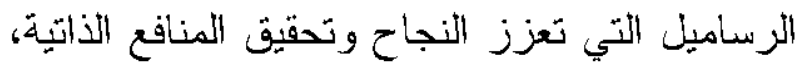
الرمزية منها و المادية عـ فرضيات البحث 
ويحقق لها الامن المهني، والرضا عن آدائها "الحياة ليست نهرا هادئا" هكذا يلخص المثل الفرنسي نظرية التغيز التي أسس عليها الفكر الفلسفي رؤيتّه للوجود وللحياة لا شيء ثابت ولا لانيات

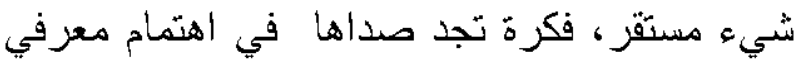
قديم وجد لدى باحثين وفلاسفة أمثال جان جالك التمان

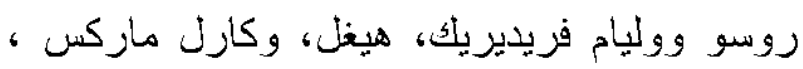
واوجست كونت ولكنه سيحتل قيمة كبرى في عشرينيات القرن العشرين وتحديدا بعد مؤلف وليام

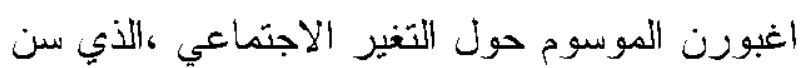
الطريق لتقدم الأبحاث العلمية حول قضايا التغير الاجتماعي كمفهوم أُثار نقاشا واسعا لشّدة صلته بمفاهيم أخرى مثل النظور و التقدم و النمو و التتمية و الحداثة.

استدعت الباحثة هذا القول ولها فيه مآرب عديدة، أهمها ما عرفته المملكة العربية السعودية من نقلة

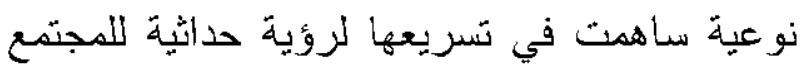

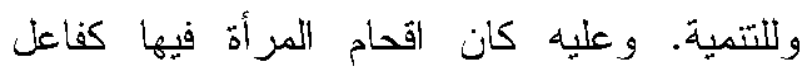
استراتيجي ضرورة ملحة تغيرت معها وضعينها

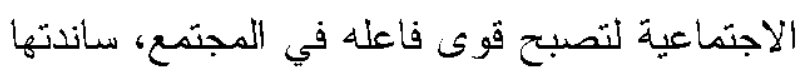

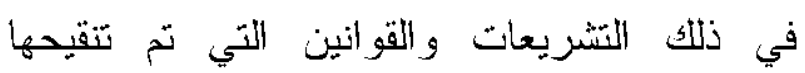
وتحديثها. قو انين تنم عن رؤية استشر افية لفاعل سياسي راهن منذ عقود على المرأة كفاعل اجتماعي، حيث اصدر الملك عبد العزيز قرارا مهنيا يقضي بإنشاء الرئاسة العامة لنعليم البنات

ونجاحاتها.

• تخلق الزساميل الاجنماعية و المادية و الثقافية

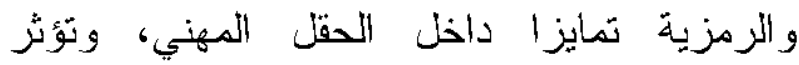
بطريقة مباشرة في تحديد الهوية المهنية لسيدات

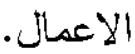
تعتبر هذه الفرضيات منطلقات أولّبة لرسم خارطة طريق أوحت بها إثكالية البحث، وهي فرضيات قابله للتأكيد أو التفنيد وفقا لما ستثبته الدراسة الميدانية التي ستجريها الباحثه في المنطقة الشرقية

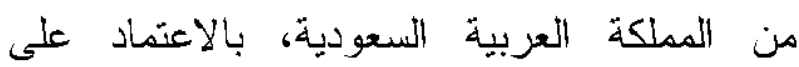
استمارة موجهة تخول لها معرفة امتدادات وحدود صحة هذه الافتز اضات. • إلمفاهيم الإجرائية للبحث الفرات لا يخلو تحديد المفاهيم المستعطلة في البحث من الأهمية التي نستوجب الوقوف عليها لتفكيك آليات

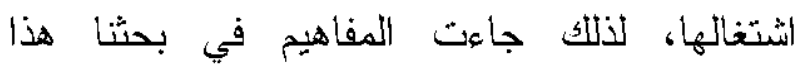
متمحورة في : سيدات الاعمال بالمنطقة الثرقية

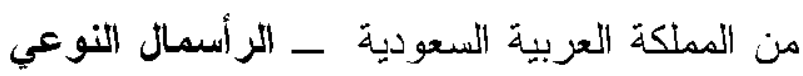

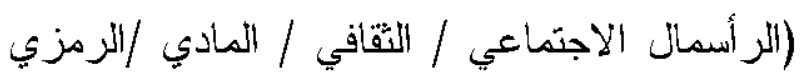

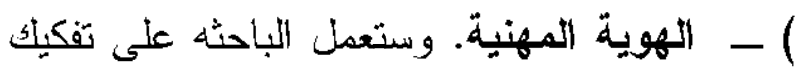

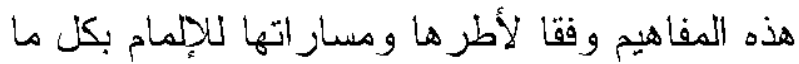
يمكن أن يخدم البحث نظريا وتطبيقيا. ا- سيدات الاعمال بالمنظقة الثرقية : مسارات التغير والحداثة 
مجالات العمل المتاحة للمزأة). قرارات كان لها الأثر الإيجابي والمباشر منها تطوز دور المرأة في

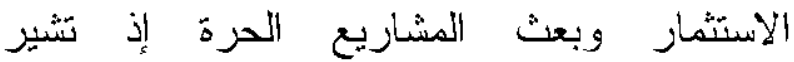
الإحصائيات إلى أن" عدد سيدات الأعمال السعوديات قد تجاوز •r ألف سيدة يمتلكن سجلات تجارية. أمَّا عدد المشاريع الاستثمارية والاقتصادية التي تمتلكها سيدات أعمال سعوديات فتجاوز الـالـ

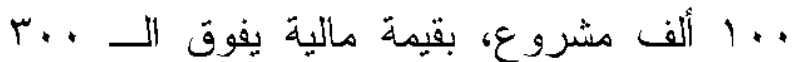
مليار ربال (·A مليار دولاز). وتشير إحصائيات عام Y. Y. إلى أن عدد سجلات سيدات الأعمال

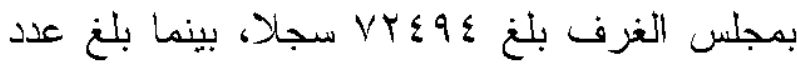

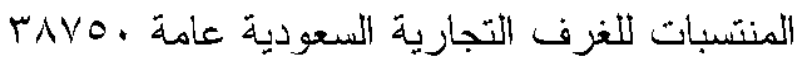
منتسبة. ويقّز حجم استثمارات النساء في السوق بنحو عشرين مليار دولار، وقد بلغ عدد الثركات

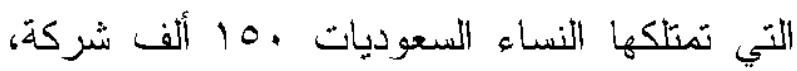
أي . 1\% من إجمالي السجلات التجاربة وتقدم الغرن التجارية والصناعية في أقسامها النسائية المستحدثة خدمات عديدة ومتتوعة للمنتسبات مثل الخدمات القانونية وخدمات التكريب و التأهيل وخدمات البحوث و الاراسات وخدات تتمبة

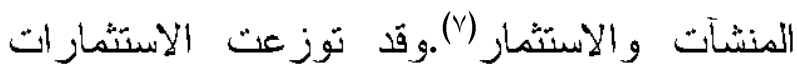
النسائية على مجالات مختلفة، مثل قطاع الذهب

- - ورقة عمل أعدتها الإدارة العامة لمجلس الغرف النسائية

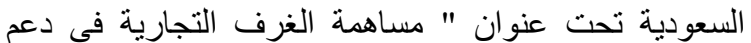

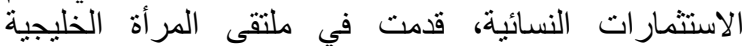

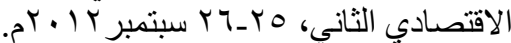

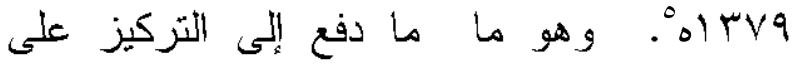
إنشر الك المر أة السعودية في التتمية كطاقة لا بستهان بها في شتى المجالات آخرها ما ورد في رؤية

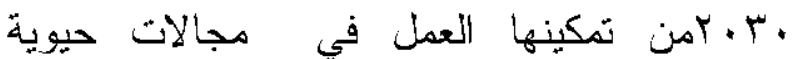
كالسياحة والاعلام ، مما ساهم في ارتفاع نسبة فئالية مشاركة المرأة السعودية في سوق العمل المحلية،

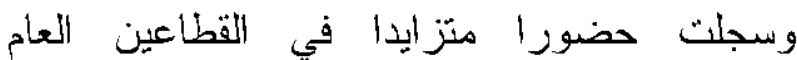
والخاص، فقد أوردت وزارة الاقتصاد والتخطيط فيطاتئ

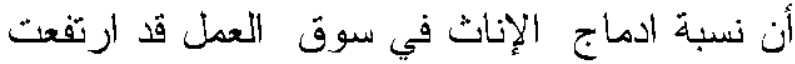

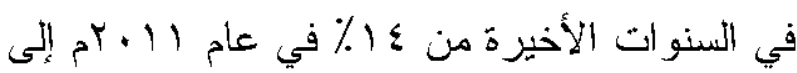

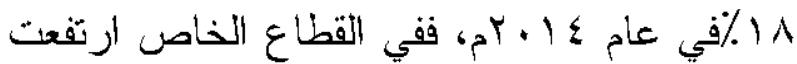

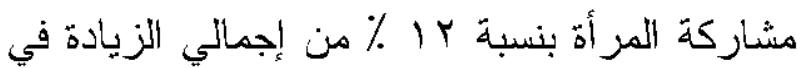
عدد الموظفين. وارتفعت في القطاع العام بنسبة العبة العابة ( 1 ) $\%$ ०र تحوّل تدريجي نحو المشاركة المتزايدة في القطاع

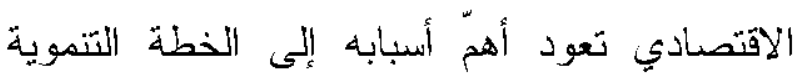

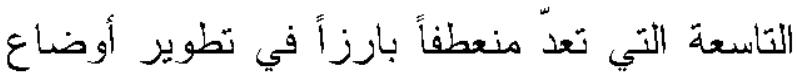

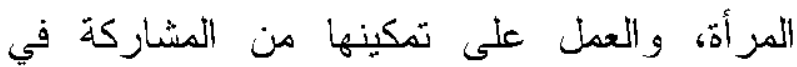
اللتمبة الاقتصادية والاجتماعية، عززتها قرارات فئات

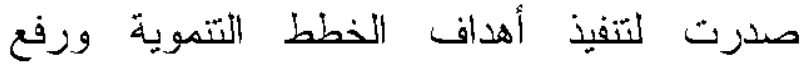
مشاركة المرأة في الإقتصاد، ومن أبرزها القران القار

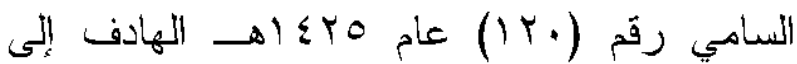
(التوسع في الفرص الاستثمارية النسائية وفي

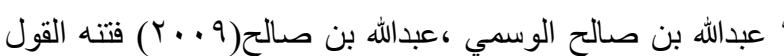
بتعليم البنات في المملكة العربية السعودية ،بيروت المبات المركز

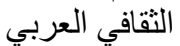
- وزارة الاقتصاد و التخطيط، تقرير الاقتصاد السعودي لعام

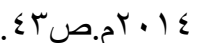


و المجوهرات وتجارة الملابس وصالونات التجميل ولعلّ ما يؤكّ نجاح هذه السياسة بروز فئة من

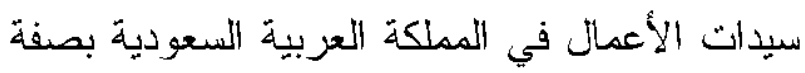
عامة، وفي المنطقة اللشرقية بصفة خاصة، وملفتة

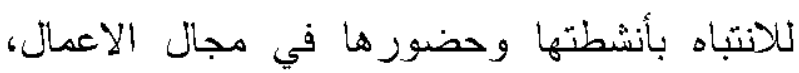

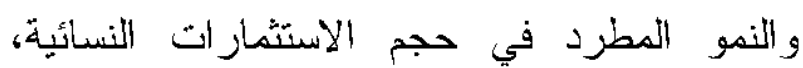
ويعود ذلك إلى عوامل مختلفة لعلّ أهمهّا توفّر

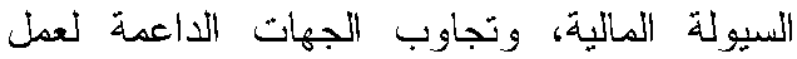

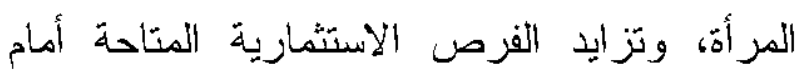

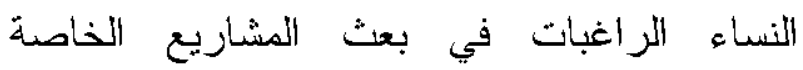
و الاخول عالم الاعمال .

لقد ساهمت وزارة التجارة في تيسير الخدمات التي لاعني تقدمها لسيدات الأعمال بالمنطقة الشرقية، وذلك فئي

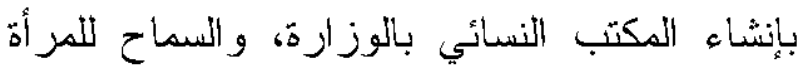
بممارسة نشاط العقار ات و المقاو لات، و إعطائها الحق الكامل أيضا بممارسة جميع الأنشطة الاقتصادية. كما كان للتسهيلات التي تقدمها أمانة المنطقة الشرقية دورا رئيسا لنمو الاستثمارات النسائية في المنطقة. وكان أيضا للبلديات دور

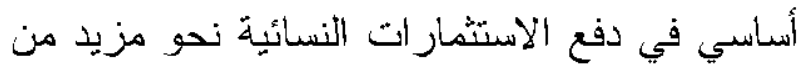
التطور، وذلك بتسهيل الإجراءات المنعلقة باستصدار رخص الأنشطة الاقتصادية، وهو ما لأنرات أدّى إلى تذليل الصعوبات وسهّل بعث المشاريع.

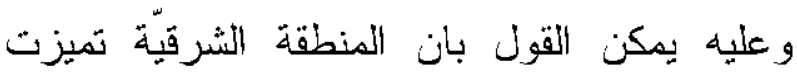
بإرساء إدارة ناجحة ومشجعة للاستثمار، نجاح

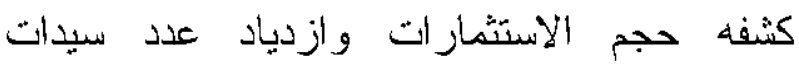

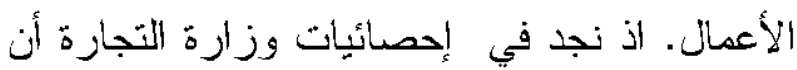
وتصميم الأزياء. وقد عرف النشاط الاستثماري

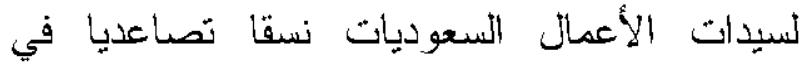
السنوات الأخيرة وتنوعت الأنشطة التجارية ما بين لأنيات

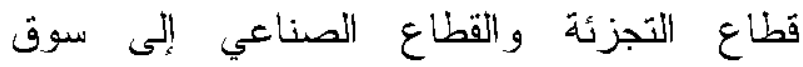

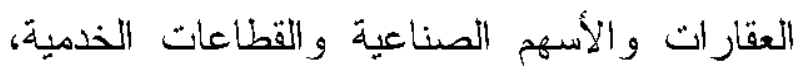

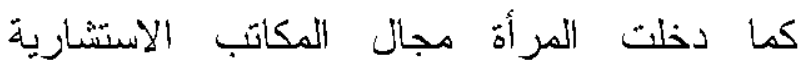
و القطاع التعليمي و الصحي. ان ما تحظى بـ المنطقة الثرقية من المملكة العزبية السعودية من مناخ ملائم للاستثمار هو هونه

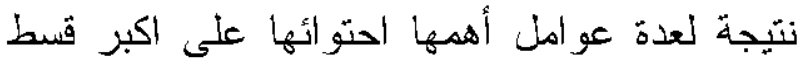
من الثروة النفطية للملكة وتواجد مساحات كبيرة

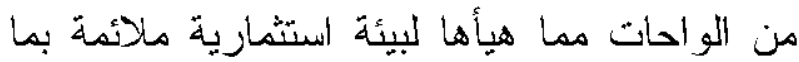

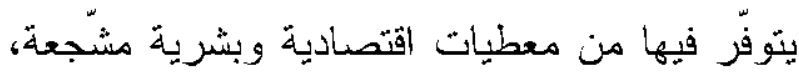

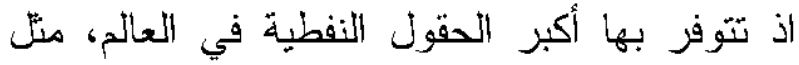

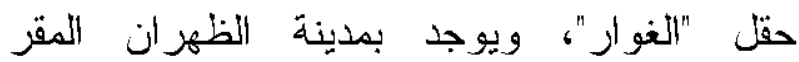
الرئيسي لشركة "أر امكو" التي تدير بو بودئ حقلا للنفط وبا حقلا للغاز في جميع أنحاء المملكة. وتمثل احتياطيات النفط في هذه الحقول نحو بr\% من إجمالي الاحتياطي العالمي، وهي عوامل أسست الثورة في الاقتصاد الوطني كثروة طبيعية هائلة تستزم ادراتها وترشيد استهلاكها طاقات بشرية وطنية، وهو ما يسمى في رؤية .ب +r "بالسعودة

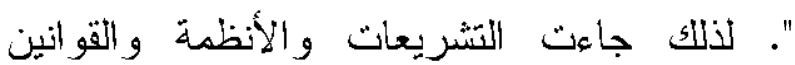
استجابة لتوجهات المملكة في تمكين المرأة وتشجيعها على العمل والانخراط بقوة في التنمية. 
الفاعلين الاجتماعيين لأي نوع من أنو اع الرساميل التي يمتلكونها، و التي يمكن ان تتحول الىى اشكال

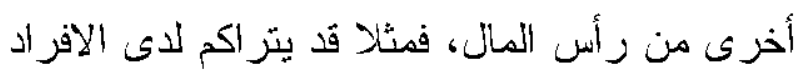

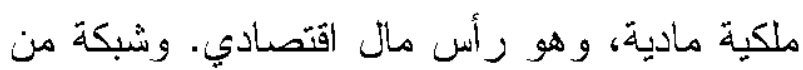
المعارف كرأس مال اجنماعي و الذي يرجعه بتتام Putnam التى مظاهز البناء الاجنماعي و الثبكات و العلاقات الاجتماعية التي تسهل التتسيق و التعاون

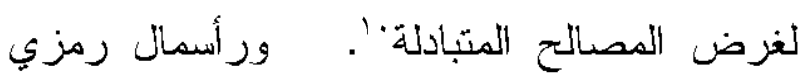
متمثل في المكانة و الميبية ،او ما بسميه ماكس فيبير

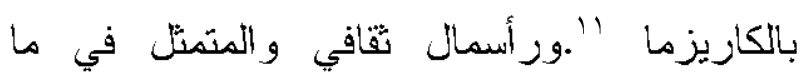
يكتسبك الفزد من مهار بات ومعارف ومؤهلات

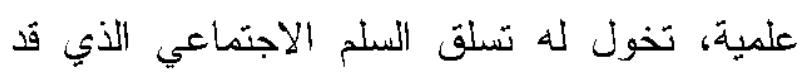

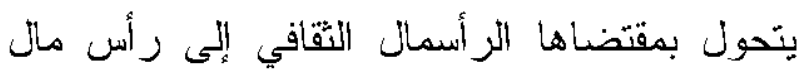

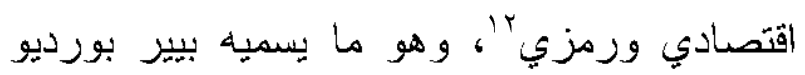

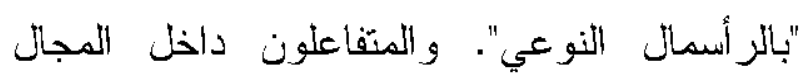
يمتلكون بالضرورة استعدادات متفاوتة بتبفاوت

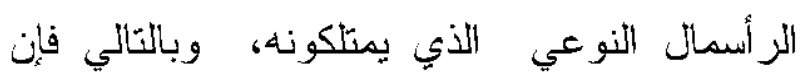
علاقات القوة داخل المجال تحدد حيازة المكانة التي لتي تتحدد بقدرة الافراد داخل هذه المجالات المتنوعة

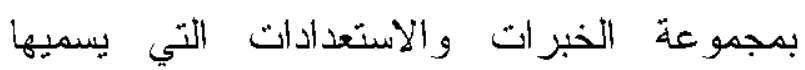

Robert Putnam,(1993)Making Democracy Work,Princeton, university press

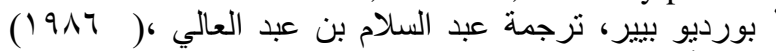

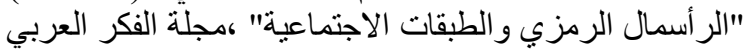

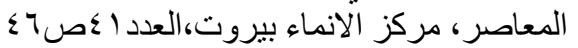

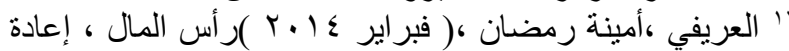

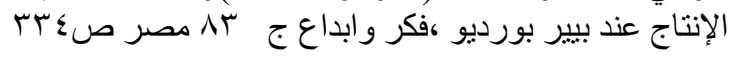

السجلات التجارية لسيدات الأعمال بالمنطقة الثرقية كان عددها ro19 سجلا في سنة ج + . Yم،

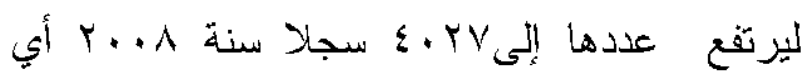
بنسبة ، 9 \%في زيادة التجارة النسائية بالمنطقة الشرقية. r

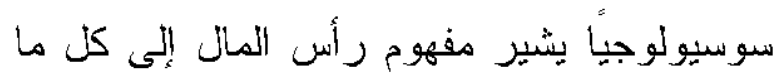

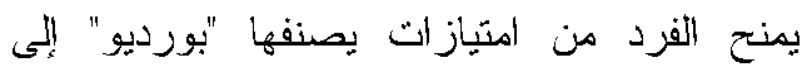
أربعة رساميل أساسية وهي : الز أسمال الاجنماعي لفئي

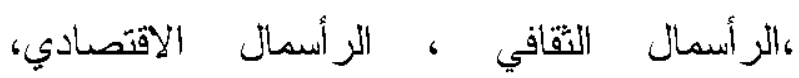
و الز أسمال الزمزي ـ تصنيف اتخذه "بورديو" كأداة

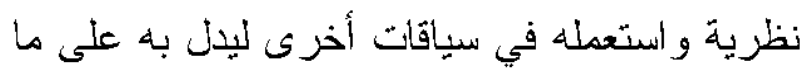

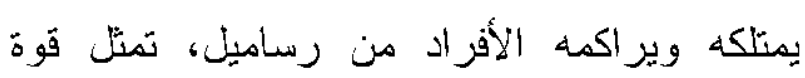

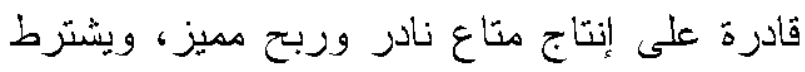
استثمار الرساميل نوفر فضاء يتافس فيه اللاعبون لتحقيق مصالح محددة، بهذا المعنى يضحى الحقل

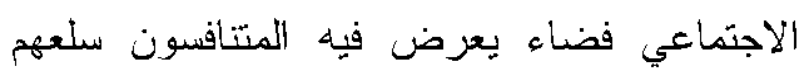

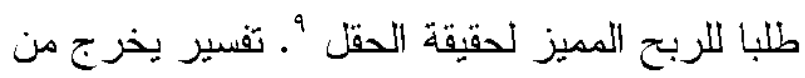
التشبيه الضيق لمفهوم رأس المال لاى كارل

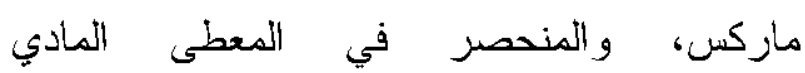
والاقتصادي، الا انهما يتفقان في التركيز على على العيز

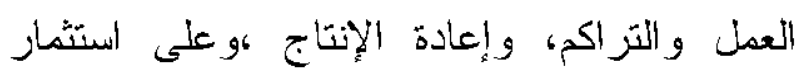

^ انظر ورقة العمل التي أعدتها الإدارة العامة لمجلس الغرف فئل

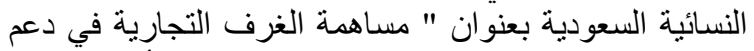

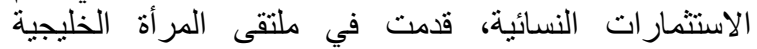

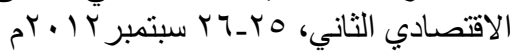

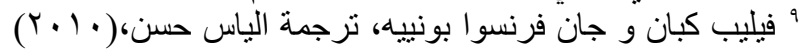

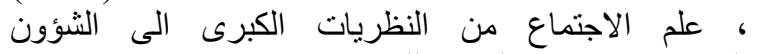
اليوميه،دمشق، دار الفرقان للنشر 
سمات ثقافية، وبشكل عام تتعلق الهوية بفهم الناس وتصورهم لأنفسهم ،ولما بعتقدون انه مهم في

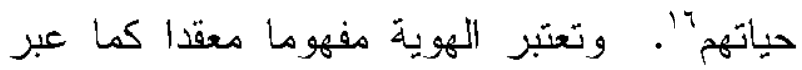
عن ذلأك روكاس Roccas وبراور Brewer لكونها تشير الىى درجة من التذاخل الملحوظ بين انتماءات الشخص لمجموعات منباينة في نفس الوقت ، وقد يكون من المفاهيم القليلة التي تجاذبتها حقول معرفية مثنوعة مثل علم الاجنماع وعلم النفس، والاقتصاد، والسياسة، و الأنثروبولوجيا، وعلم اللغة، ورو ما يطرح إتكاليات الاتفاق حول جوهر هذا المفهوم وحول المكونات الفاعلة فيه، هذا بالإضافة الكى تتوع اشكال الهوية (فردية، شخصية، مهنية، وطنية، ثقافية، دينية، عرقية، اثثية)، وهو ما يضفي مزيدا من الصعوبة على محاولة الوصول القى نتائج نهائية قابلة للتعميم. وما يهم من هذه التعريفات هو الولوج التى المفهوم الأساسي في البحث وهو الهوية المهنية ولئن كانت دالة على هوية أشخاص معينين ،فإنها كانت ثقوم في الوقت ذاته بحشر مجموعة بشرية محددة داخل صنف اجتماعي يتميز عن الآخرين بممارسة مهنة أو حرفة ما ،و هذا الانتماء كان أيضا بيبغ على هؤلاء الافزراد جملة من السمات أو الخصائص

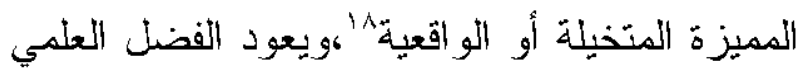

17 غدنز انتوني،مرجع سابق Castel Manuel(2004),the power of identity,2 edition London “' جراي فتحي ،سوسيولوجيا الخدمة الاجتماعية، ص VI ا مرجع سابق

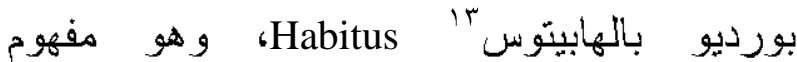
بورداوي بامتياز استعمله للالالة على مجموع الاستعدادات الجسدية و الذهنية الذائمة، التي تترتب على عملية التتشئة الاجنماعية للفرد، و التي تجعل منه "فاعلا اجنماعيا Social Agent "في إطار حقل اجنماعي معين Social champ ،حيث بعيش ويشتخ بصفته حيزا في العالم الاجنماعي كمفهوم أوسع و أعقد من مفهوم الاذات؛ '.

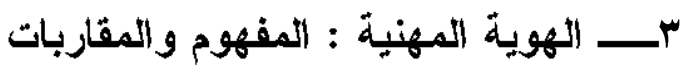
في معرض الحديث عن الهوية المهنية كمفهوم مركزي في هذه الدراسة تجدر الإشارة التى مفهوم الهوية الذي بحمل دلالة لغوية ،وفلسفية، و اجتماعية، وتثافية، ويعني مفهوم الهوية الإحساس بالانتماء القومي و الديني والاثتي "، وقد عرن بيكنغهام Buckingham اللهوية بانها مفهوم زئبقي غائم ، على اعتبار ان الهوية تعني التماهي هع الآخرين الأين نشابه معهم على الأقل في بعض لئ لئ

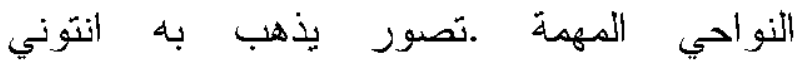
غدنز Antony Giddens بعيدا ليشيز التى أن الثهوية هي بناء من السمات اللثقافية أو إلى مجموعة ذات

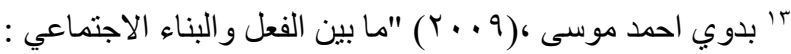

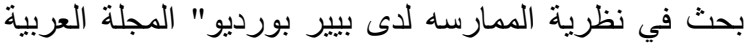

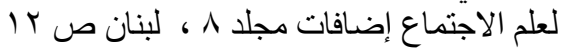

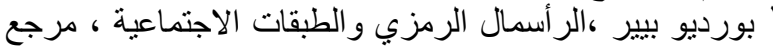

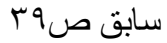
ما الضبع ماهر عبد العال ،(10 م.ب)،"ملامح الهوية لدى أبناء

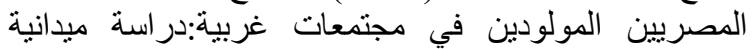

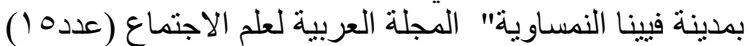

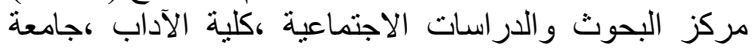

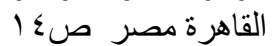


وبصمات البعد الأقافي 19 ، بمعنى أننا أمام مجتمع مؤسسة بحيث يكون الفاعل ملتزم بقو اعد وضوابط هذا المجنمع، أي أن سلوكياته نعكس امنثاله للقيم و المعاييز المنتجة جماعيا عبر التفاعل اليومي بين مختلف الفاعلين الاجتماعيين. و لأن تحقيق الذات

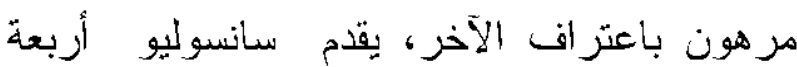
شروط لتحقيق الاعنز اف بالذات و الآخر تتمثل في

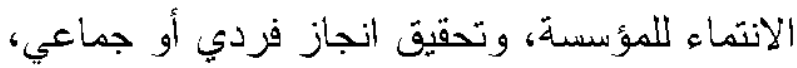
و المسار الثخصي المهني، و القدرة على مقاومة كل أشكال الهيمنة التي تفرض في مجال العكل، كما يوفز جو الثقة المتبادل بين مختلف الفاعلين حيث تصبح عملية التعاون ممكنة وعلاقات العمل أكثر ألفة و وانسانية تساعد على تحقيق الاندماج الاجنماعي والتنظيمي، مما يعزز الشعور بالانتماء إلى المؤسسة ، و التُعرف على المشترك بين كل فئة و أخرى ،وبذلك بينحقق الوجود المهني للفاعل بالمؤسسة، ومنه نتحدث عن تشكل الهويات المهنية لمختلف الفئات المهنية. مقاربات لم تغب عنها الأعمال الرائده لكلود دوبار Claud Dubar حول الهوية و الثهوية المهنية، مشيرا الى ان الفرد لا يمكنه أن يشكل هويته بمعزل عن الآخر وأحكامه وتصوراته عن الأنا، حيث تتشكل الهوية المهنية من خلا لالهوية الثخصية و الهوية الجماعية وتفاعلات ذلك مع المهنة أو الحياة المهنية. فالشعور بالهوية المهنية
في ادراج مفهوم الهوية في علم اجنماع الشغل الفرنسي إلى سانسوليو Sansaulieu؛ باعنبازه أول

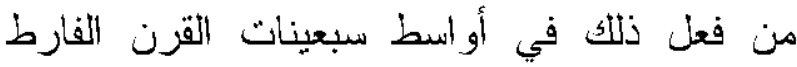
وكان قد عرف الهوية و المقصود بها تحديدا الهوية في العمل، باعنبار ها طريقة من طرق التموقع ،أي

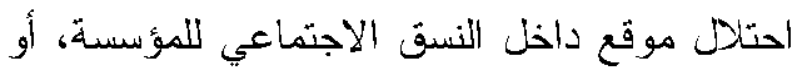
هي أيضا كيفية من كيفيات الارتباط بالزملاء

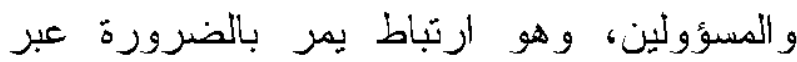

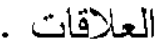
هنا تتزاءى للباحثه الكوية المهنية ضدن سياقات مختلفة، فسانسوليو يختلف في مقاربته عن المدرسة التفاعلية الرمزية على اعتبار انه لم يشتغل على لئل المسار الههني، أو على الابعاد الأتية مركزا على لـى اللسياق الحاضر الأي ينتج الهويات في العكل، ومعارضا ما جاءت به المدرسة الوظيفية الى ابراز الهوية المهنية من خلا مظاهر التضامن والانسجام بين المنتمين الىى مهنة واحدة، إذ يستتد سانسوليو في تحديده للهوية المهنية على المقاربة التقافية و التي تنظر إلى المؤسسة ليس كمجال مختصر حول عملية الإنتاج ، بل انطلاقا من كون المؤسسة مجال للتشئة الاجتماعية وتشكل الهويات الفردية والاجتماعية حسب القيم و المعايير التي تشكلت عليها بنية المؤسسة ، بمعنى أنه بنظر للعامل ليس كفاعل منفذ بل كفاعل منتج ومبدع يساهم في إنتاج و إعادة إنتاج ثقافة المؤسسة ، لذلك فان الهوية المهنية عند سانسوليو لها سمات 
دراستتا للظواهز الاجتماعبة، خاصة اذا ما ارتبط الأمز بتغير في اللبنى الذهنية والحرالك الثقافي والاجنماعي والاقتصادي في مجنمع كان يتسم بالانغلاق. ولذلك فقد اختارت الباحثة أن نتقصى موضوع هذه الدراسة حول دور الرأسمال النوعي في تحديد الهوية المهنية لسيدات الاعمال السعوديات بالاعنماد على نظريتي البنائية الوظيفية و التفاعلية الرمزية، ولنا في ذلك مبررات منهجية و علمية ،أولها ان التفاعلية الزمزية تقوم ابحاثها بالأساس في مجال المهن و انماط التبادل و التو اصل

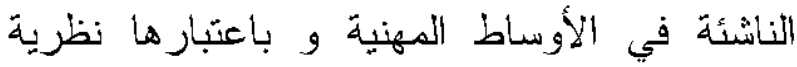
تزكز على فهم التفاعل المتبادل و الأات الاجتماعية داخل مجتمع يعايش أعلى مستويات التصنيع و التحضر و نزعات الإصلاح و النزعة العملية و لعابل المثالية، و من ثم كان وعي الإنسانية بذاتها يتز ايد تبعا لذلك ،و بعتبر هذا الاتجاه حديثا في علم

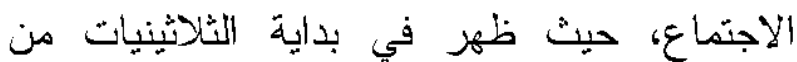

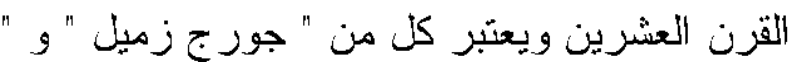

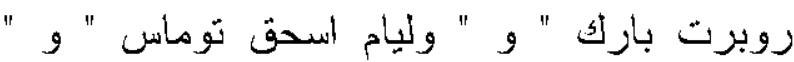
شارلز هورنون كولي "و " جون ديوي " اهم رواد نظرية التفاعلية الرمزية'ب ،التي تساعد على تحليل وفهر عمليه التفاعل الاجنماعي التي يكون فيها الفرد على علاقه و اتصال بعقول الاخرين، و حاجاتهم ورغباتهم الكامنة ووسائلهم في تحقيق الاهذاف. و عليه فقد اهنم " زيميل " بالتفاعل و وليان

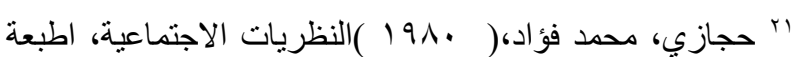
الأولى ،القاهرة، دار غريب للطباعة.
هو محصلة للعلاقات التفاعلية المطورة ضمن ميدان العمل، وبنائها أي - الهوية المهنية - عبر شكلين من مسار المعاملات ، الأولى تعامل موضوعي من خلا الآخرين بمعنى هوية معينة،

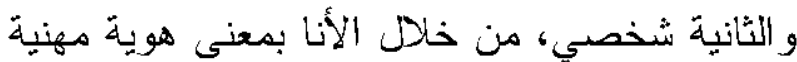

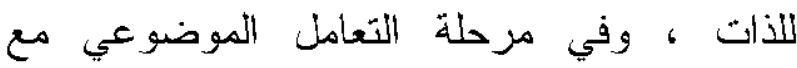
الآخرين يتطلع الفرد لاستيعاب نوقعات الأدوار لتحقيق الاعتزاف من عدمه، بينما التعامل الذاتي الداخلي يمكن أن يعرف من خلا بعدين وهما:

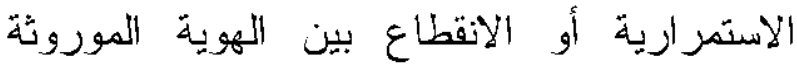

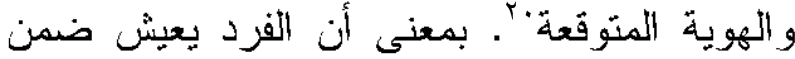
تفاعلات جمعية لتحقيق الأات، بحيث لا يمكن أن يكون للانا معنى إلا من خلال وجود الآخر. مثل

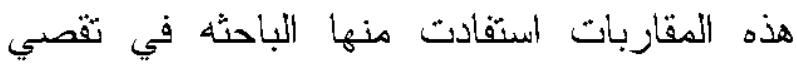
آليات اشتغال أنواع الرأسمال ودورها في تحديد الهوية المهنية لسيدات الاعمال بالمنطقة المرقية وفقا مقاربات تمثل خارطة طريق الدراسة نظريا

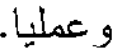

\section{؛ـــــــــ الاطار النظري للبحث}

ان ما تعيش على وقعه المجنمعات المنسمة بالايناميكا والانفتاح على الحر الك العالمي قد أحدث تغير ات جذريه وحركية مستمرة على مسنوى اللنى الاجتماعية و الثقافية و الاقتصادية، و هو ما يستو جب في الدراسات الماكرو -والميكرو سيكولوجية حذر ابستمولوجيا تفرضه الضرورة العلمية في

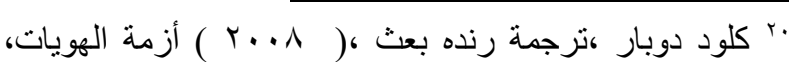
الطبعة الاولى كبيروت ، الدكتبة الثرقية. 
النظرية من تحليل لميكانيزمات اشتغال المجتمعات هو في ارث دوركايم Durkheim ما يشهد له بالريادية في هذا المجال، خاصة وانه اشتغل وبامتياز على مكانة العمل في المجتمع ويعتبره اهم الأسس التي انبنى عليها المجتمع الحديث، لذلك جاء تقسيمه للمجنمعات عمليا لمجتمعات تقليدية تقوم على التضامن العضوي ، و أخرى حديثة يكون التضامن فيها آليا والتنظيم المهني بها يؤدي وظائف اجتماعية تهيكل المجنمع وفقا لهيكلة أصحاب المهن و المنتمين الى الحقل المهني نفسه. اذا يبدو هنا البراديغم الوظيفي الدوركايمي مؤثرا في علم اجتماع المهن ،خاصة و انه اثز في العديد من المفكرين اهمهم بارسنز Parsons الذي تجلى تأثزه بوضوح في نظريته حول الفعل الاجنماعي، مؤكدا على مقولة تفرد الحضارة الغربية بنشأة فئه

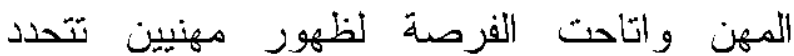

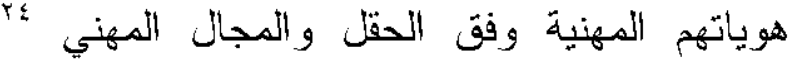
ووطالما استخدم الوظيفيون ومنهج "أوقست كونت و "إيميل دوركهايم" مبدأ المشابهة العضوية للمقارنة بين عمل المجتمع بما يناظره في الكائنات العضوية. وبالتالي فإن تحليل الوظائف التي يقوم بها أحد نكوينات المجتمع يتطلب منا أن نبين الدور الذي تلعبه في استمرار وجود المجنمع ودوام

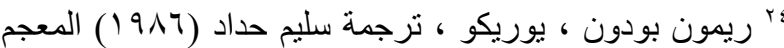
النقدي لعلم الاجتماع ، بيروت ، المؤسسة الجامعية للاراسات

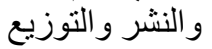

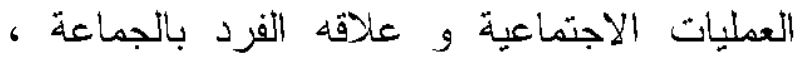
وذكر ذلك في كتابه (علم الاجنماع) الذي أصدره سنة 19.1/مّ حول الفعل المتبادل أو الأفعال المنبادلة بين مجموعة من الأفراد بشكل تتاوبي.

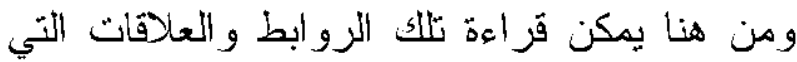

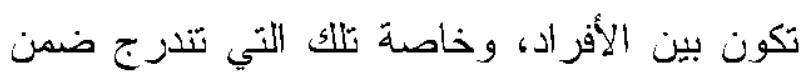
التفاعل الاجتماعي الحي أو المشاركة المجتمعية، لهنه فالثرد يكتسب تقافه جماعته فتصبح الاسس

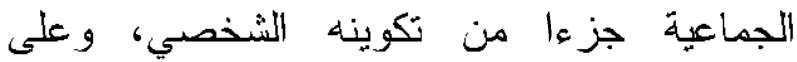
أساسها يذهب ميد الى تصوره للعلاقة التبادلية بين الأات و المجتمع، كحصيلة تبادل مستمر بين العقل البشري و النفس البشرية ،كما يشكلان أُصلا عن طريق التفاعل، فالاتصال الترمزي هو أساس كل

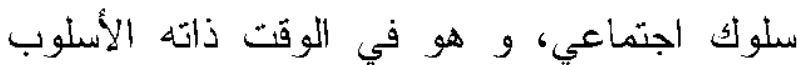
المنهجي الملائم لاكتساب المعرفة عن هذا السلوك

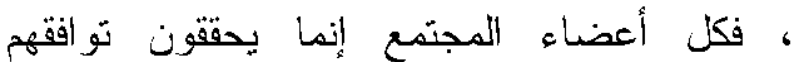
المنبادل من خلال مواقف يفسرون فيها السلوك إنكا

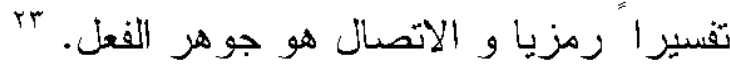
تحليل تجد فيه الباحثنه ضالتها فيما بخدم البحث في حدود ما تسمح به إنتكالية وفرضيات الأراسة ،ولفهم أكثر عمقا لدور الرأسمال النوعي في تحديد الهوية المهنية لسيدات الاعمال ،استعانت الباحثه ايضا بنظرية البنائية الوظيفية لما تُقده هذه

Simmel, George (1976) The Stranger The Sociology of Georg Simmel' New York: Free Press

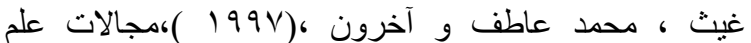
الاجتماع المعاصر ، الإسكندرية ، دار المعرفة الجامعية.. 
التقصي والأمام بتحليل الحالات المنفردة، وقد

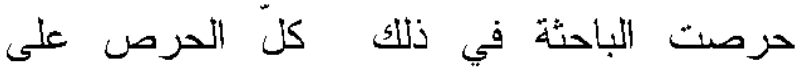
الانطلاق من الؤ اقع، ومن رصد مختلف التغيزات و التفاعلات للوصول إلى طريقة عملية وبناءة للوصول الى نتائج علمية. 0ـ الادر اسات اللسابقة

حاولت الباحثة الاطلاع على جهود الباحثين ذات

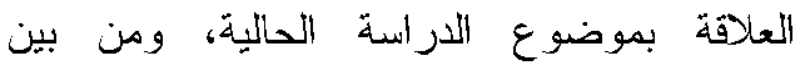
الدراسات التي أمكن للباحثة الوقوف عليها دراسة الباحثة ميسون بنت علي الفايز في دراستها المو ارد البشرية النسائية السعودية : نحو اطنار استراتيجي

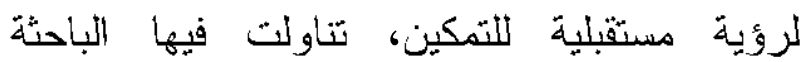
المعوقات الذاتية التي تزتبط بشخصية المرأة إلى لرقال

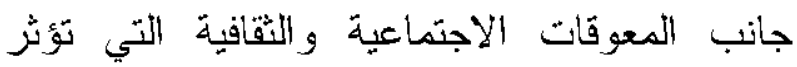
على دروها في العمل وفي التنمية ، إلى جانب

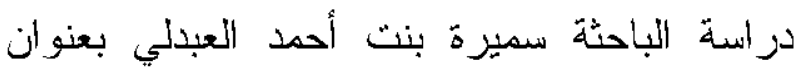
المشكلات التي تواجه سيدات الاعمال وعلاقتها بالمهارات الإدارية، طرحت فيها الباحثة أهم هذه المشكلات الاجتماعية و المادية و الثقافية التي تعرقل مسار سيدات الاعمال وتحول دون تحقيقهن للأهداف المنشودة في مجال الاعمال. هذا بالإضافة

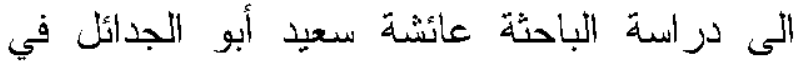

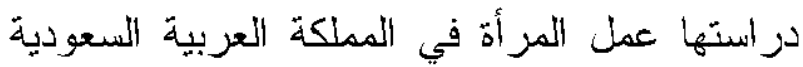
نظرة تاريخية، و الذي حاولت فيه الباحثة الوقوف على المسار التاريخي لتطور المرأة في المجال المهني وريادة الاعمال ومسيرتها واهم المعوقات عافيته(ro)و عليه فان هذه النظرية البنائية الوظيفية

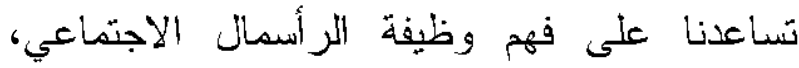
و الثقافي، و المادي، و الرمزي في تشكيل الهوية المهنية داخل الحقل المهني، المطبوع بتمايز هذه الرساميل، و العوامل المؤسسة لهذه التراتبية بين الافراد داخل نفس الفضاء المهني. وهنا يمكننا الإشارة اللى ما سعت اليه هذه النظرية التي درست المهن والهويات المهنية بشكل أساسي التى تنظيم

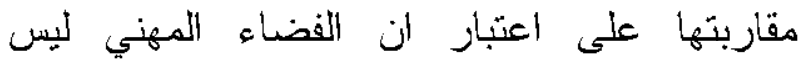
اشتخالا بقدر ما بمثلك من انتماء تبديه مجموعة اعنة

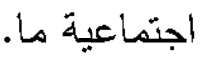

ويأتي توظيف كل من نظريتي البنائية الوظيفية

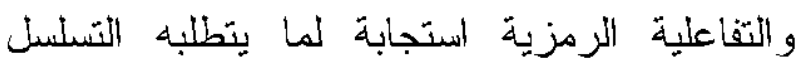

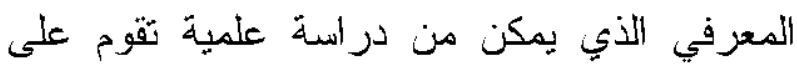
البناء الذهني و المفاهيمي كأدوات علمية ،للوصول دئل اللى نتائج موضوعية و اعنمدت الباحثة في ذلكئة منهج المسح الميداني لتجميع المعطيات الأساسية

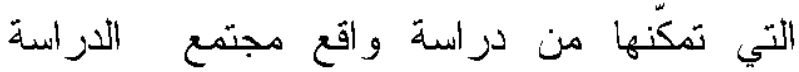

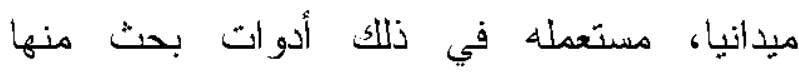

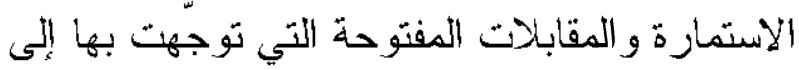
عيّنة عشوائية ضمت ، ، سيدة أعمال بالمنطقة الشرقية كنموذج للار اسة. وقد اعتمدت الباحثنه على تحليل البيانات المجدعة بعد معالجنها إحصائيا للوقوف على أهمّ النتائج التي توصلت اليها البحث بعث ووظفت هذه الأدوات العلمية لما لها من نجاعة في لهي

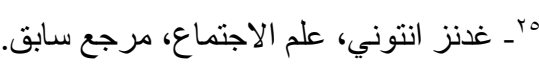


الأهداف والحصول على منافع ذاتية ومصالح تكسب الفرد مكانة اجتماعية داخل الحقل المهني و الفضاء الاجنماعي ، هذا بالاضافة إلى دراسات

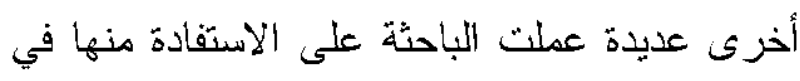
حدود ما يخدم البحث ويساعد على الوصول إلى على التى نتائج علمية. الاطنار التطيقيّي عانه

يعتبر المناخ الاستثماري بالمنطقة الثرقية حافزا

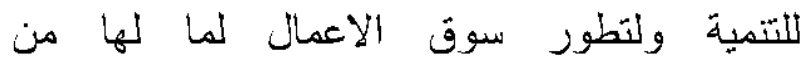
خصوصية وحر الك اجتماعي و اقتصادي، ساهما في لتمدي تيسير اقتحام سيدات الاعمال لفضاء عملي وحني برساميل متنوعة شكلت لهن هوية مهنية تحددث

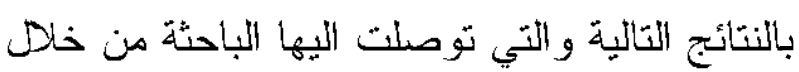
العمل المبداني أولها:
التي تواجهها .في حين استفادت الباحثة مما قدمه الباحث حسين سالم ضيف الله الشر عه في دراسته الامن النفسي وعلاقته بوضوح الاحوية المهنية و التي سعى فيها الباحث التى تقصي حقيقة علاقة الامن النفسي بوضوح الهوية المهنية. وفي دراسة الخها

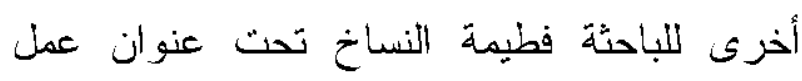

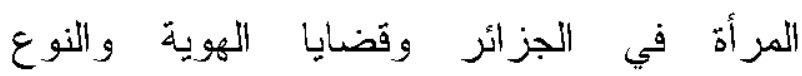
الاجتماعي تتاولت فيه الباحثة أهم ما يشكل الهوية الهية

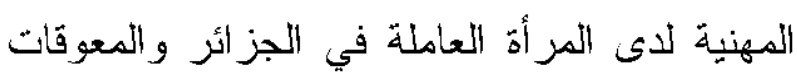
الاجنماعية والثقافية التي تواجهها وتمثل عائقا للنجاح .بينما استفادت الباحثة من دراسة قدمنها الباحثة امينة رمضان العزيفي بعنوان رأس المال

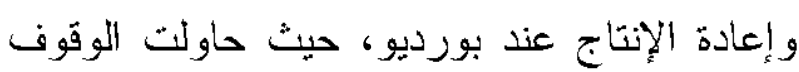
على أنواع الرساميل الاجتماعية منها و والمادية و الاجتماعية و الرمزية و الثقافية، ودور ها في تحقيق الزيق ا لـــــائص سيدات الاعمال بالمنطقة الشرقية

\begin{tabular}{|c|c|c|c|c|}
\hline & $7 .-\sum 7$ & $\leqslant 0-r\}$ & ro-ro & 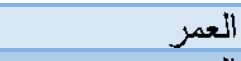 \\
\hline & IV & $Y \leq$ & 19 & العدد العد \\
\hline & $\%$ rq & $\% \varepsilon$. & $\%$ & النسبة \\
\hline أرملة & مطلقة & منزوجة & عزباء & الحالة الاجتماعية \\
\hline 0 & $\wedge$ & rq & $\wedge$ & العدد \\
\hline$\% 9$ & $\% 1 r$ & $\% 10$ & $\%$ & النسبة \\
\hline جامعى ج ج ج & ثانوي & ابتدائى & أمى & المسنوى التعلنيمى \\
\hline ro & YV & 0 & $\mu$ & العدد الم \\
\hline$\%$ \% & $\%$ \% & $\% 9$ & $\% 7$ & النسبة \\
\hline لاشيء & هونى & أدبى & علمى ل عي & التخصص \\
\hline & 9 & Y & Y & العدد \\
\hline$\%$ & $\% 10$ & $\% \leq \varepsilon$ & $\%$ ro & الأنسبة \\
\hline
\end{tabular}

والجامعي، و هو ما يدل على قدرة المملكة العربية السعودية على الارتقاء بوضعية المر أة و وادماجها

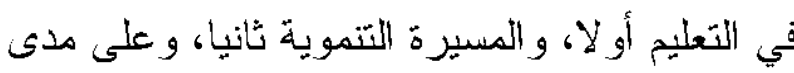

بالوقوف عند خصائص سيدات الاعمال بالمنطقة الثرقية تطرح الكثير من الالالات أولها

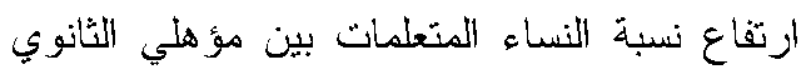


بمعوقات ثقافية عملت المملكة على تخطيها من خلال سن قوانين وتشريعات لتمكين المرأة فئه السعودية من التموقع في المجنمع، وجعلها فاعلا اجتماعيا مساهما في المسيزة التنموية وهو ما ذهب في وهي إليه بييز بورديو في تصوره للفعل الاجتماعي بانه لا يتحقق الا من خلاهل مؤسسات المجتمع مهما كانت درجة بنائيته، كما أن المجنمع لان لأن بمكن تفريغه من الذوات الفاعلة "فالكائنات البشرية تضفي

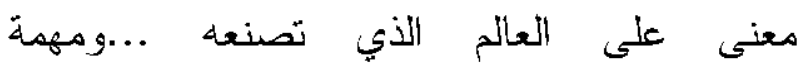
السوسيولوجيا كثف اعمق البنيات الافينة لمختلف العو الم الاجتماعية وكذلك الآليات التي تضمن إعادة

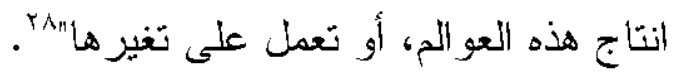
وبالنظر إلى الحالة الاجنماعية للمبحوثات عينة الدراسة نجد أن المتزوجات يمثن النسبة الأعلى

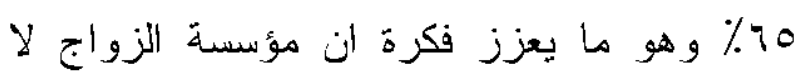
تمثل عائقا أمام سيدة الاعمال للنجاح ،خاصة وان الباحثه تتحدث عن نموذج اجتماعي حديث بدأ يعرف انفتاحا و إعادة تشكل وفق منظور حداثي من بينها الاسرة و العلاقات الزوجية في ضوء العلاقات الثخصية التي تربط بين الزوج وزوجته، وبين الزوجين والأبناء(ه)وفي هذا المسار ذهب أيضا آلان توران في قزاءته لهذا التفاعل داخل مؤسسة الزواج، باعنز افه ان التفاعلغت هي علامة بلوغ بلون

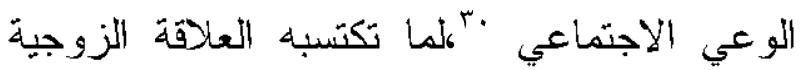

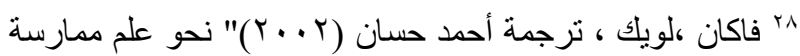

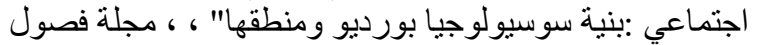

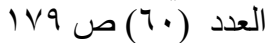
ه' اجلال إسماعيل،حلمي (1999) العنف الأسري ،مصر، دار قباء

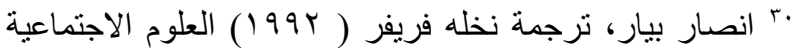

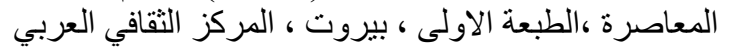

قدرة انخر اط المرأة السعودية في المجالات العملية التّي كانت حكرا على الرجال من خلال ريادتها الاعمال، حيث تتركز النسبة الأعلى لإى الفئة

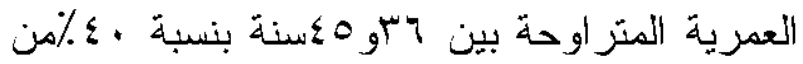

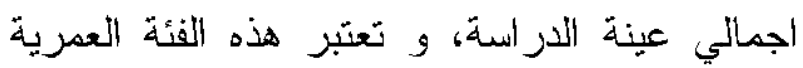
الأكثز نشاطا وانخر اطلا في مجال الاعمال خاصة اذا ما اقترنت بارتفاع نسبة المتعلمات و المتزوجات في تقارب بين المجالين الادبي والعلمي المنز اوحة

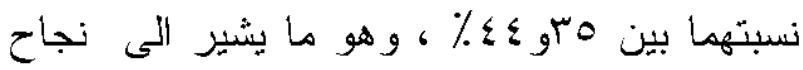
الخطة التعليمية بالمملكة العربية السعودية منذ عقود و التي اعطت أكلها بمرور الوقت، و يؤكد النظرية

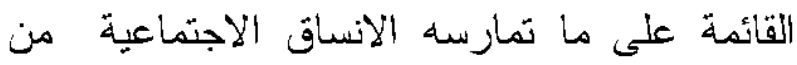

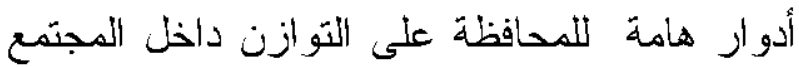
من خلا ما ثقدمه من خدمات وبر امج عدة سواء كانت صحيه، أو تعليميه، أو مهنيه، وبالتالي فهي مني

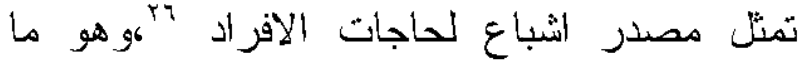

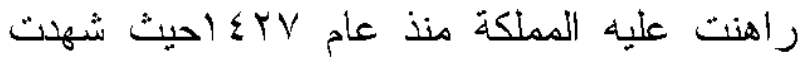
ارتفاع في معدلات تعليم المرأة وفقا لبيانات وز الرة التعليم العالي الو اردة في الخطة الثامنة والتاسعة من اجمالي الملتحقين في بر امج البكالتوريوس كانوا من الاناث بنسبة بلغت 79٪، كما بلغت نسبة الخريجات خلال السنوات الأربع الأولى هن خطة

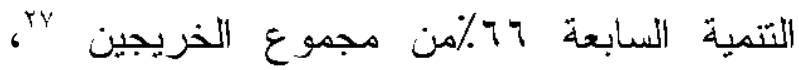
و عليه فقد حقق المخطط التنموي أهدافه من خلا

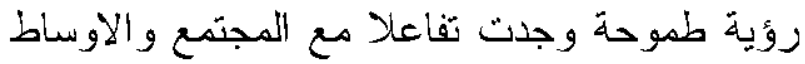
الاجتماعية المختلفة كرغه غو انه انه يصطدم أحيانا

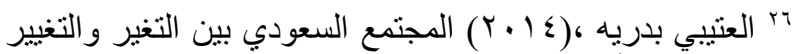

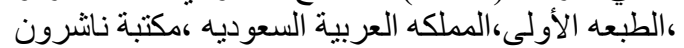

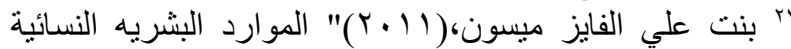

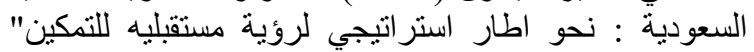

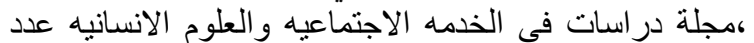

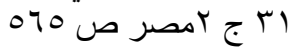


اجتماعيا مؤثرا في الديناميكا الداخلية والخارجية للمجنمع السعودي.
من منافسة وتعاون لم يكونا مطروحين في السابق

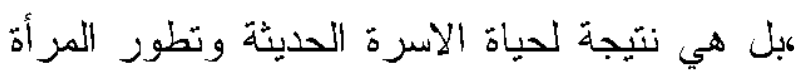

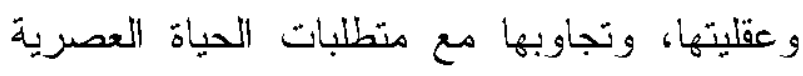
التي خلقت استر اتيجيات جديدة تحدث عنها ميشال كروزييه باسهاب ضمن دينامية اجتماعية خاصة

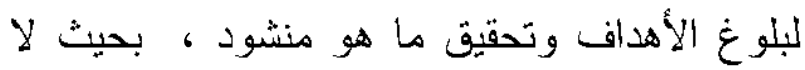

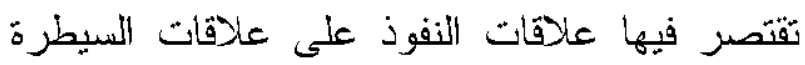

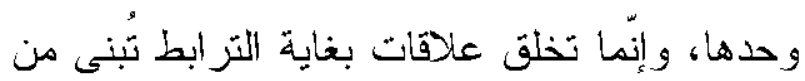

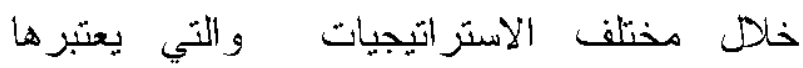
"جورج لابساد - Georges lapassade" و"رينييه

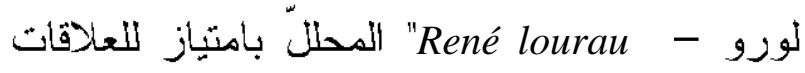

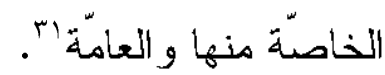
اذا يبدو جليا من خلا المعطيات التي توصلت اليها الباحثة في هذا الجدول تأثير التعليم وتغنير

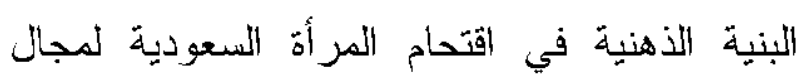
الاعمال، خاصة في مجنمع ذكوري لم يكن يؤمن

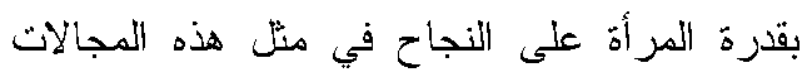

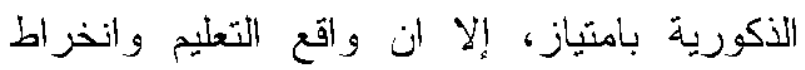

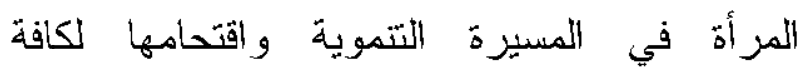
القطاعات وتثلدها مناصب عليا، الى جانب التشريعات و القوانين التي ساعدتها على تحقيق ما

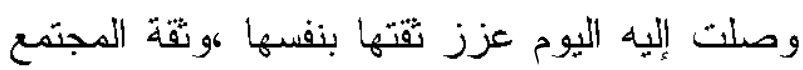

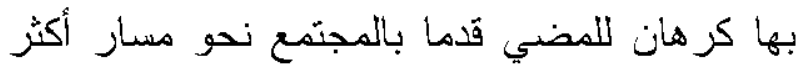

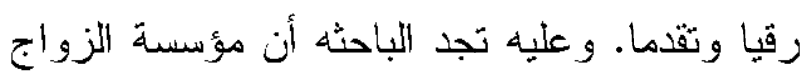

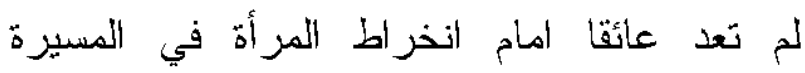

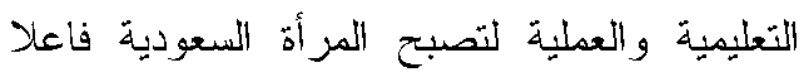

31 Crozier,Michel and Friedberg,Erhard(1980),Actors and systems,Chicago, university of chicago,press, 2 


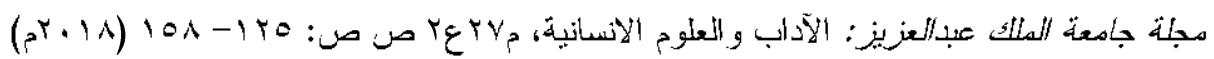
DOI:10.4197/Art.27-2.5

r الأصول الاجتماعية و الز أسمال النوعي لسيدات الأعمال بالمنطقة الثشرقية

\begin{tabular}{|c|c|c|c|c|}
\hline خدمات & فلاحة & صناعة & نجارة & القطاع ع \\
\hline 1. & ir & ir & $r \varepsilon$ & العدد \\
\hline \multirow{7}{*}{$\% 17$} & $\%$ Yr & \%YY & $\% \varepsilon$ & النسبة \\
\hline & التبدو & القزى & المدينة & الانتماء الجغز افحى \\
\hline & 1. & 11 & rr & العدد إن \\
\hline & $\% 17$ & $\%$.r. & $\%$ \% & النسبة \\
\hline & فقير & متوسط & ثزي & الانتماء الطبقى \\
\hline & 9 & rr & rq & العدد \\
\hline & $\% 10$ & $\%$ rv & $\% \leqslant \wedge$ & النسبة \\
\hline
\end{tabular}

المؤشرات العادية للتراتبية الجنسية القائمة على أسطورة المؤنث الأبدي، و المذكر الأبدي، أو تأبيد

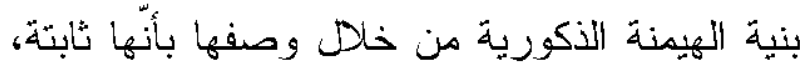

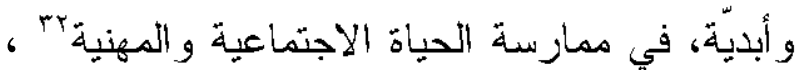

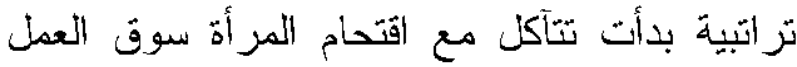
وتغير الصورة النمطية التي يحملها المجتمع عنها، لذلك فإن إعادة تشكيل الطبيعة من جديد تمثل على الصعيد الثقافي في إعادة صياغة لنظام اجتماعي

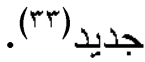
وبالرجوع إلى الانتماء الجغرافي فقد بدت نسبة سيدات الاعمال المنحدرات من المدينة هي الأعلى بما يناهز ؛ه\% أي أكثز من نصف عينة الأدرة ،في حين تأتي القزويات في المرتبة الثانية بنسبة ، r\%، في وقت تشكل فيه المنتميات التى البدو 7 \%٪. تصنيف هرمي يكثف عن مدى قدرة

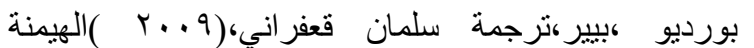
الذكورية، بيروت، مركز دراسات الوحدة العربية ،المنظمة

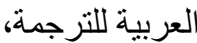

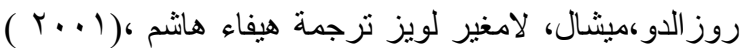

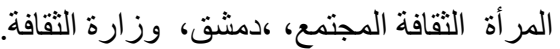

تكشف المعطيات المتوفرة في هذا الجدول آلية من آليات اشتغال المجنمع السعودي ضمن رؤية حداثية انخرطت فيها سيدات الأعمال من مختلف الانتماءات الجغر افية، و الطبقية بالمجتمع السعودي، حيث تجد الباحثة ان نسبة المقبلات على قطاع

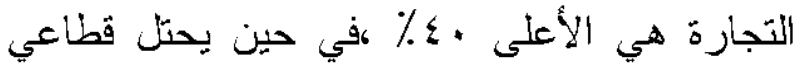

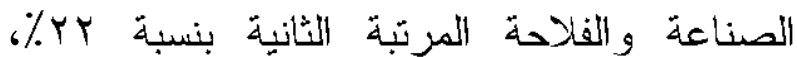
ويأتي الاقبال على مجال الخدمات بنسبة أقل تمنل 17 1\%ن اجمالي العينة، وهو ما يدلل على أن لن المر أة السعودية لم تعد تخشى اقتحام مجال الاعمال المنافسة للرجل ،خاصة وان التجارة "شطارة" كما عبرت عن ذلك الكثيز من مقولات الناشطات في

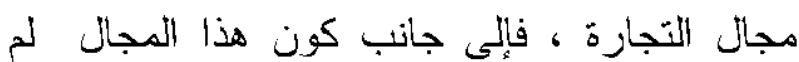
يعد يخضع لسيطرة الزجل كحقل ذكوري بامتياز، ما يجعل الباحثة نعيذ النظر في كيفية قراءة علاقة

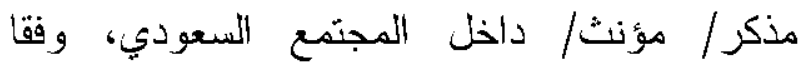

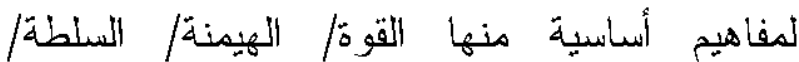
الهابيتوس، كمكونات تبنى عليها العلاقات بين الجنسين. و إلىى أي حذّ يمكن القول باختفاء 
طبقي، واغنزاب على صعيد البنية التحنية في نطاق الأسرة:(") . خطاب يجد جذوره في ثقافة مجتمع تستند إلى الى إرجاع مؤسسي كما يسميه ميشال فوكو وإرجاع

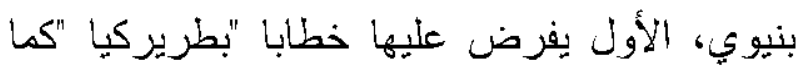

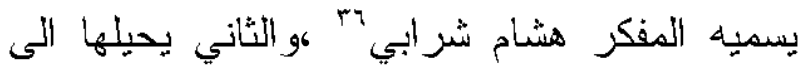

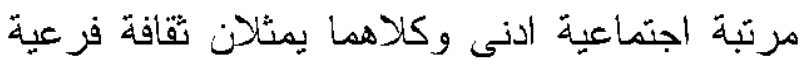

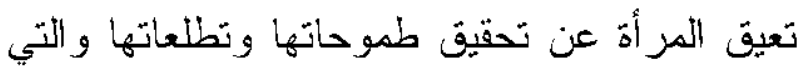
تمثل أقلل حدة وسطوة في المجتمع الحضري وهنا نتحدث سوسيولوجيًا عن ظاهرة تنشكل داخل بنية ثابتة كتب عنها دوركايم قائلا "لا شك أن الظاهرة التي تتعلق بالبنية لها من الثبات أكثر مما للظاهرة الوظيفية، لكن بين هاذين النظامين من الوقائع ليس هـئ ثمة الاختلاف في الدرجة، فالبنية نفسها قد نجدها عن طريف السيرورة... فهي تتكون وتتفكيك دونما انقطاع، إنها الحياة وقد توصلت إلى درجة من فئن المتانة، وبالتالي فإن تميز ها عن الحياة التي انبيقت

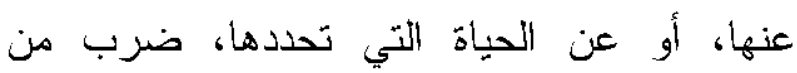

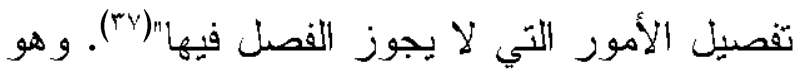

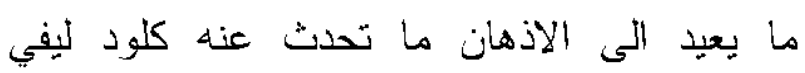
ستز اوس في ابحاثه القى اختلاف القيمة التي تسبغها

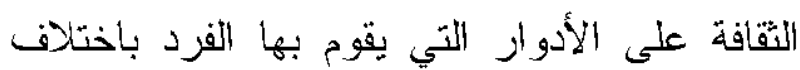

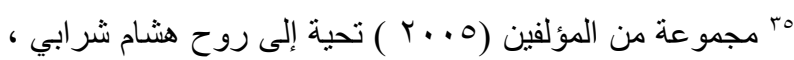
ط اتونس ،المجمع التونسي للعلوم والآداب والفئ الفنون بيت الحكمة،

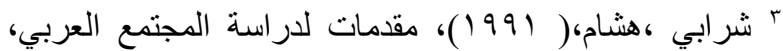

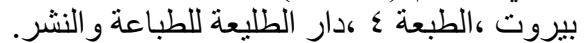

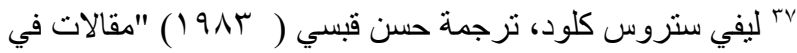

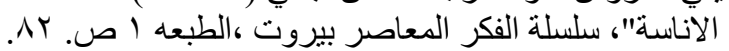

البنية الأهنية حسب الانتماء الجغر افي على التغير وقبول انخز اط المرأة في ريادة الاعمال، و الأبي يدل على ان المنتميات اللى المدينة وكن قد صرحن بان هذا الانتماء الجغرافي حقق لهن الاستفادة

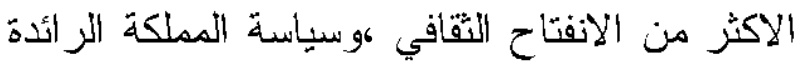

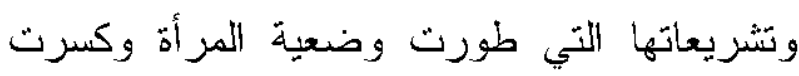
ولو إلى حد ما الصورة النمطية التي يصفها الباحث

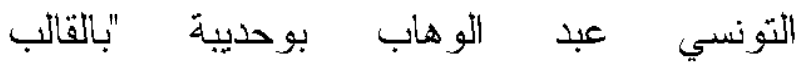
الاجتماعي"،و هو المهيمن داخل نسق اجتماعي

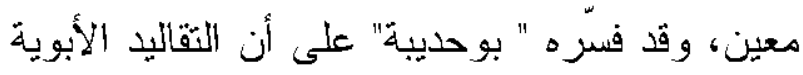

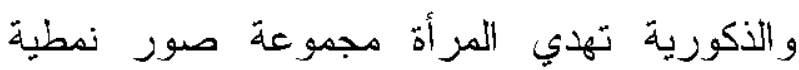
تخرج المرأة من طور الفعل والمعنى إلى العجز و اللامعنى ؛'ب صورة نمطية تتحدث عنها المنتميات اللى القزى و البدو اذ يسهين في الحديث عن ان

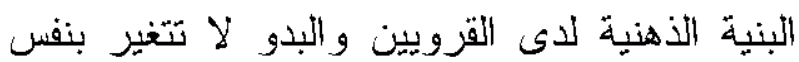
النسق كما هو عليه الحال بالنسبة للحضر ، اذ يجدن صعوبات كثيرة للانحاق بمثل هذه الاعمال نظرا

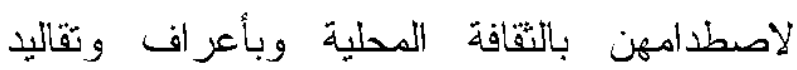
العائلات والقبائل التي لا تتقبل التغيير بسهولة، وهو ما يجعل المرأة خاصة المتعلمة و المنتمية للقزى وخاصة البدو تشعر بما تسميه الناقدة خالده

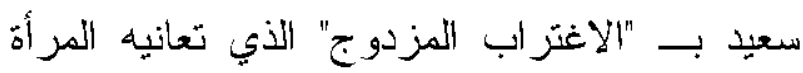

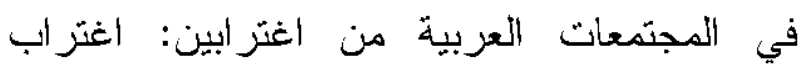

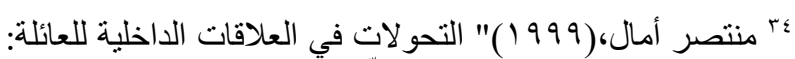

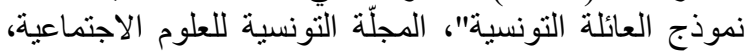

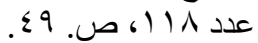


في السلم الاجتماعي. وما يمكنتا استنتاجه من هذا وذالك أن الر أسمال المادي والاجتماعي تبدو آليات اشتغالهما متباينة من فئة إلى أخرى. آليات تعبر

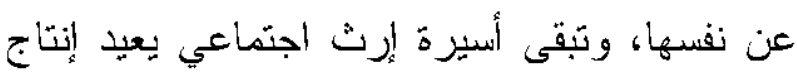

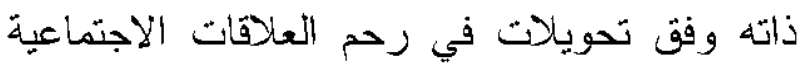
الصراعية التي تميز بين بنية تحتية وبنية فوقية

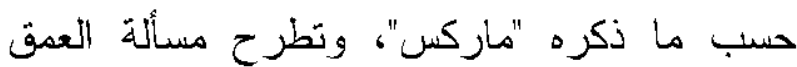

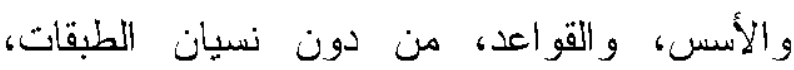

$$
\text { حسب "ثورفينش". •؛ والحسب، }
$$

إذا تبدو مسألة التزاتبية الاجتماعية مطروحة من خلال هذا الجدون رغم أنه يجدر القول ان هنالكك نسبة من المنتميات إلى الطبقتين المتوسطة و الفقبرة حقنن نجاحات بحكم تعليمهن وارتقائهن السلم

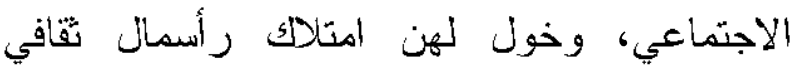

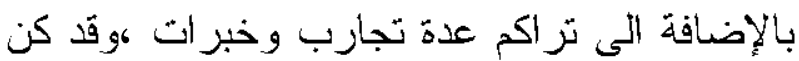

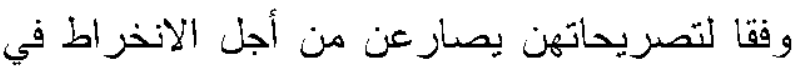
الحراك الاجتماعي الذي حققن من خلاله نجاحات و تموقعا في عالم الاعمال، حزالك يقع في رحم

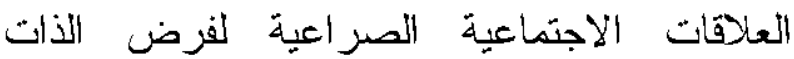
تخلص إلى تكريس اختلافات حقيقية في الفضاء الاجتماعي "؛ ، وهو ما ذهب إلإيه بورديو في مشرو عه الفكري عندما أر اد أن يفهم دور الفاعلئ بالفين في ظل التقسيم الطبقي داخل المجتمع فقام بنحت

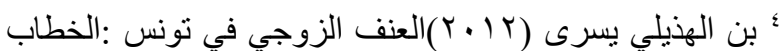

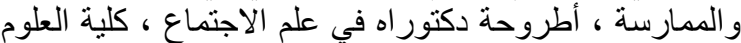

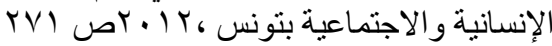

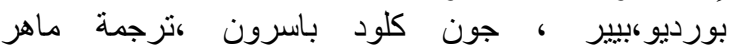

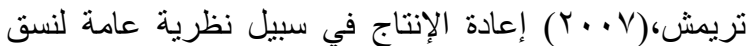
التعليم ، ط (،بيروت ، ،المنظمة العربية للترجمة الإنتاجة
الثقافات من مجتمع لآخر، وقد ذهب الى القول بوجود بعض أوجه الشبه بين معظم الثقافات حول ولان وضع المرأة، اذ تسبغ الدلالة والاهمية الكبيرة للأدوار التي يقوم بها الرجل، بينما تهمش أدوار

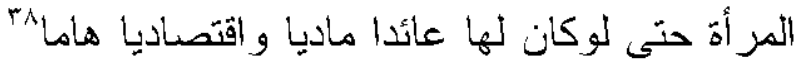
و وعليه يبدو الالنتماء الجغرافي محددا اساسيا. لاقتحام المرأة لدجال الاعمال لها تلعبه الثقافة

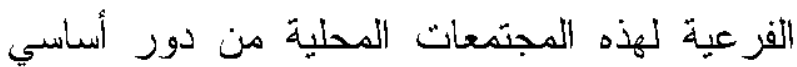
في مدى قدرة المر أة على الانخر اط في هذا المجال

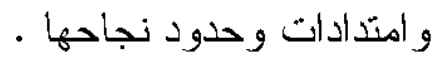
انتماء جغرافي لم يكن أقل تأثيرا من الانتماء الطبقي لعينة الدراسة على اقتحام المر أة السعودية الستية مجال ريادة الاعمال ،حيث نجد وفقا لهان الجدول الأني يبين أن نسبة المنتميات الى الطبقة الثرية هي

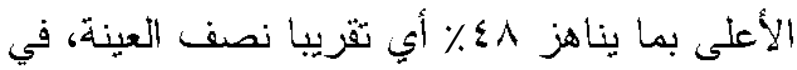

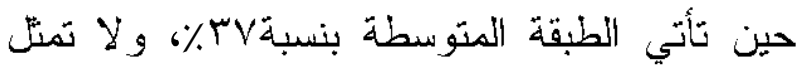

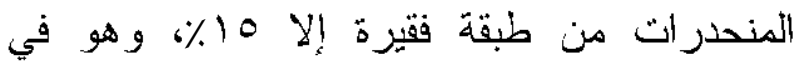
الحقيقة تدرج هرمي تفرضه طبيعة الطبقة الاجتماعية التي تحدد الر أسمال المادي و الاجتماعي اللفرد، كمجموعة من العلاقات الفعلية أو الكامنة

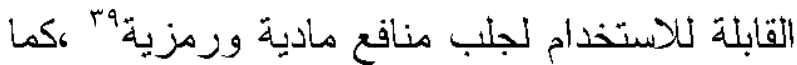
يراها "بوتنام" إلى جانب بيير بورديو كآليات تبدو

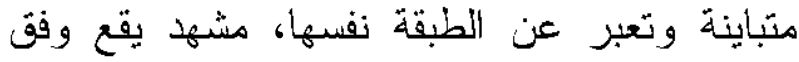
"تراتبية" ضمنية، تفرضها طبيعة الطبقة وموفعها

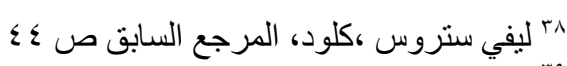

Putnam.Robert"Bowling (1995)Alone.america's Declining Social Capital"journal of democracy vol.6, p62 
المؤسسات العامة و المدنية ؛؛ ، وهو ما أفضت إليه هذه الدراسة إذ تخلق كل طبقة اجتماعية الهابيتوس وله الأبي يوجه سلوك أفرادها، وهو ما تسميه الباحثة "فزجيينيا ووولف" " خطوط تماس غيبية" باعتباره يمثل طقسا رمزيا للهيمنة، هيمنة أحد الطرفين

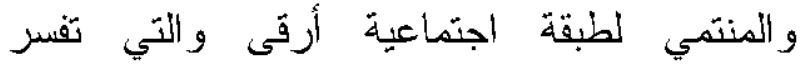

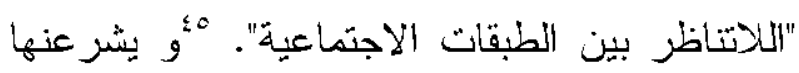
الر أسمال المادي ويمنحها سلطة ووجاهة اجتماعية المينة لا تحيا مثلما رآها بورديو إلا في غفلة عن مسلماتها المخفية في فضائها الاجنماعي، أو كما رلأيا يقول بورديو "ان ندرس الثروط الاجتماعية لإمكانية ممارسة السلطة"، تميز سلطوي تحيل اليه عينة بحثا خاصة المنتميات اللى الأوساط الاجتماعية الثزية و الناتي حققن من خلال الر أسمال المادي وجاهة اجنماعية وهيمنة عبر الرأسمال الزمزي وقد سماها بورديو هنا "بالخيمياء الرمزية وهئه

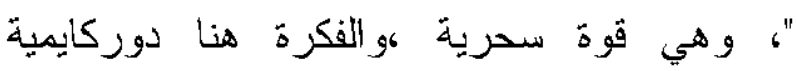
استعار ها من مفهوم "المانا" تجعل من كل خاصية

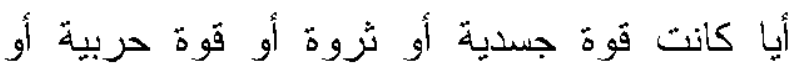

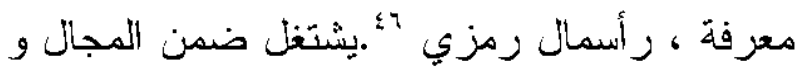

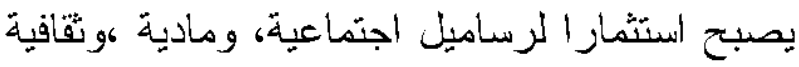

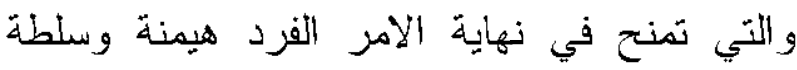

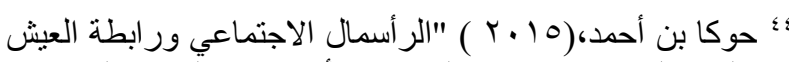

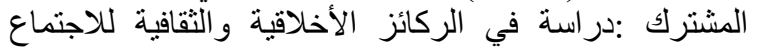

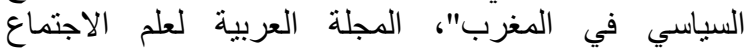

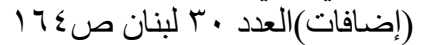

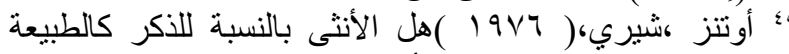

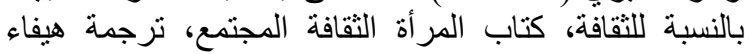
هاثشم، دمشق وزارة الثقافة. ج؛ بورديو بيير ، جان كلود باسرون ، إعادة الإنتاج ،مرجع سابق
مفهوم الهابينوس الذي عرفه على أنه " عبارة عن

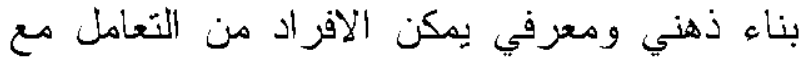

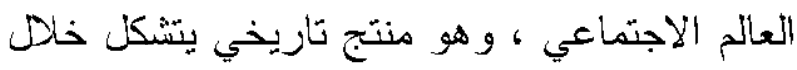
التنشئة الاجتماعية وبو اسطة التعليم ،فعبر التنشئة

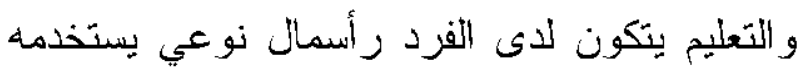
بشكل لا ارادي أثثاء الممارسات المختلفة بك داخل المجال و هو الفضاء الأي تتم فيه عمليات انتاج وتوزيع و واستهلاك و واستثمار مختلف أشكال الرساميل الرمزية و المادية و الاجنماعية و التقافية

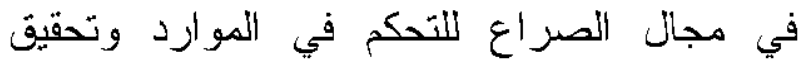
المصالح ، صراع بين القادم الجديد من طبقة اجتماعية ادنى و الأي يحاول اختز اق حدود المجال

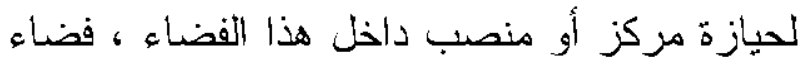
ريادة الاعمال و الفاعل المنمركز داخل المجال الذي يحاول الافاع عن احتكاره للمركز، ويحاول

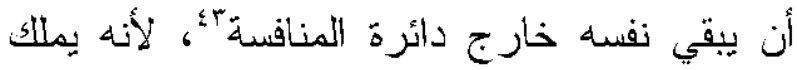

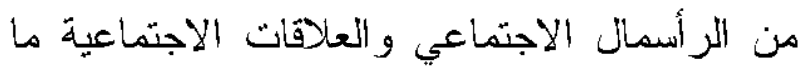
يحصنه من فقدان مركزه او يهدد مصالحه وفق

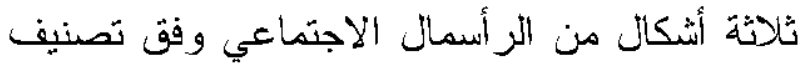

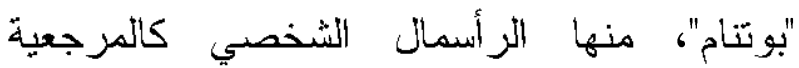

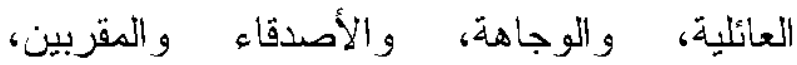

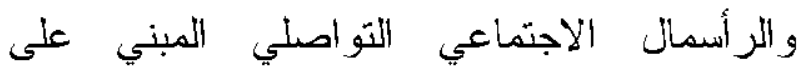
علاقات التجاور السكني أو المهني، و التواعي أسمال المؤسساتي القائم على الارتباطات الوجدانية مع الون

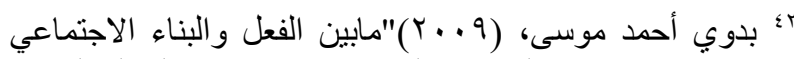

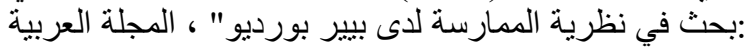

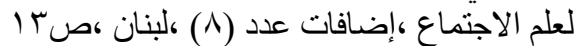

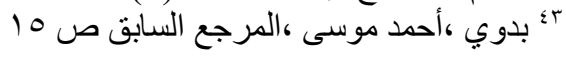


داخل الفضاء، وهو ما عملت نسبة كبيرة من وعلاقات التفاعل بين التأثير و التأثز، التسويق

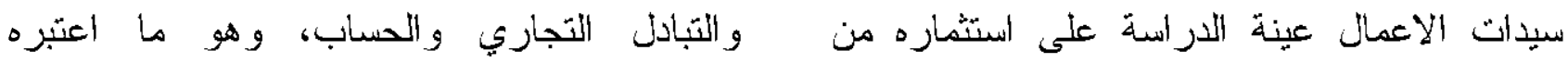

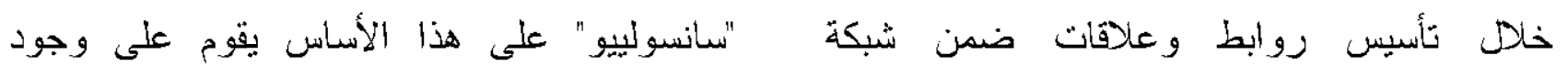

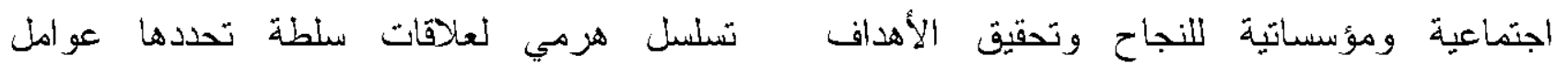

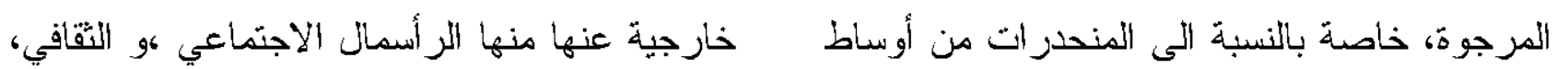

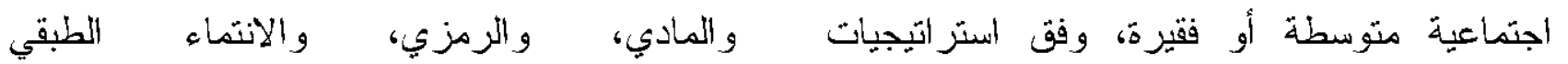

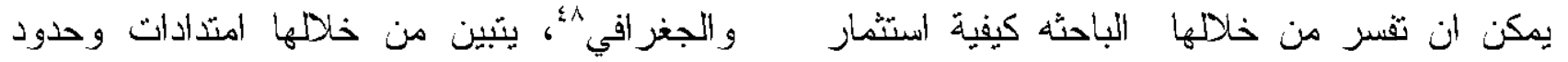

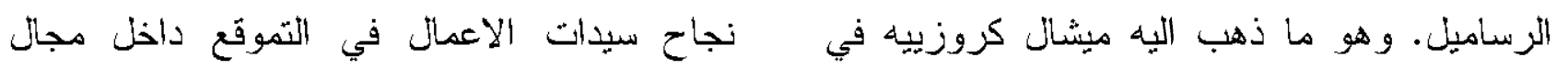

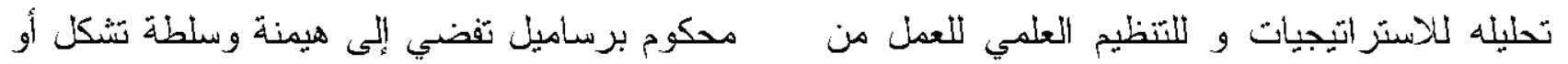

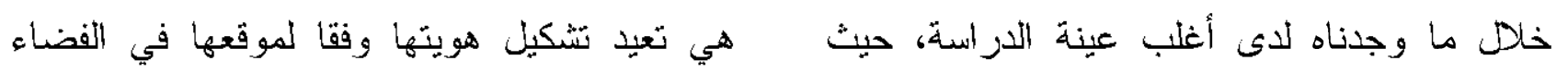

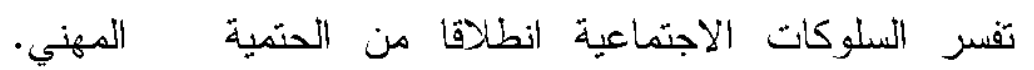

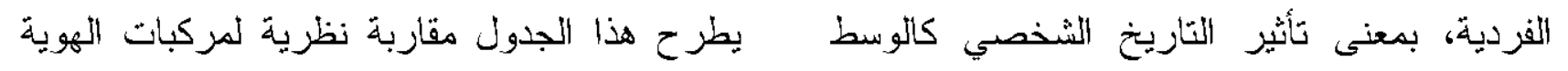

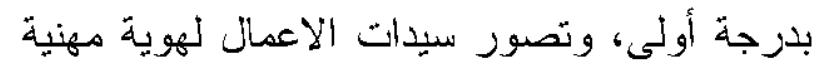

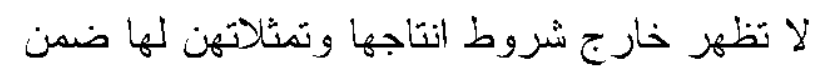
تحليل بنيوي وظيفي ،خاصة اذا ما توحدت الآراء حول مركبات الهوية الشخصية حيث تثفق كل

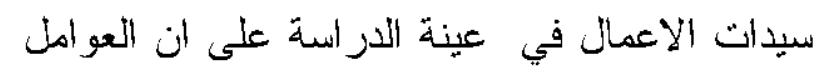

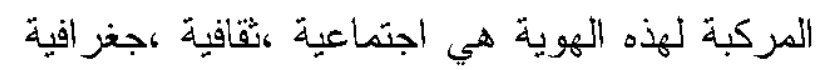

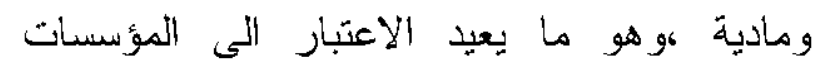
الوسيطة التي تذخل في صياغة الهوية وتشكيلها بما فيها الاكراهات الاجتماعية المصاحبة لمسارات

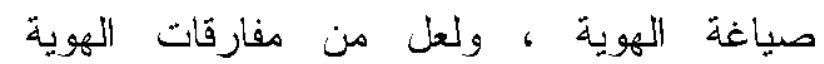

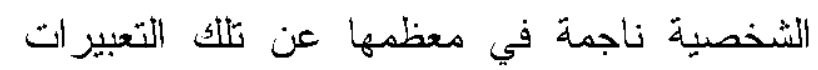
المنوتزة والتي تحيل إلى مجموعات متعددة من فئل

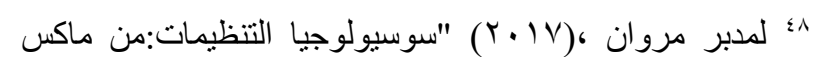

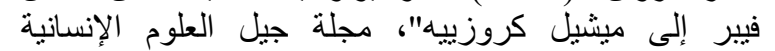

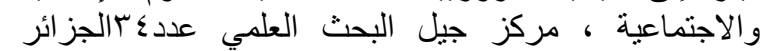

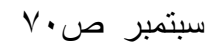
الاجتماعي، العائلي، و الطبقي، وفي سلوكات الفرد، وهو الهابيتوس و ما يعرف أيضا بالنزعة وفئية السوسيولوجية التي يمثلها ايميل دوركايم الأي يحدد

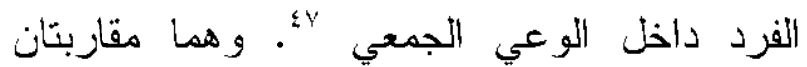

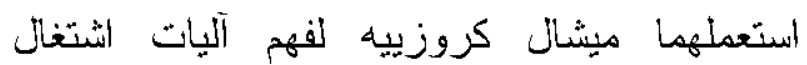
الفاعلين داخل التنظيمات و الفضاءات المهنية.

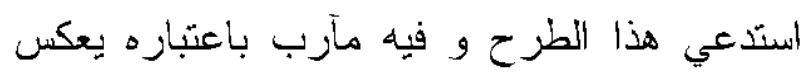
المجال المهني لعينة البحث، اذ لكل سيدة رهاناتها

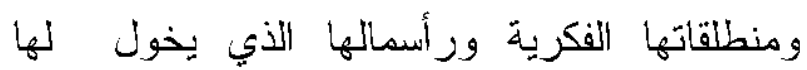
كفاعل تبني استزراتيجيات محددة بهدف الزبح و المنافع الأتية. استز اتيجيات استفادت منها الباحثة

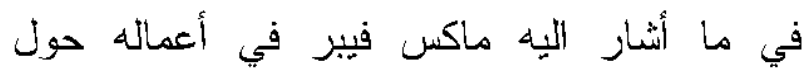
العقلانية و البيروقز اطية و العلاقات الاجنماعية التي فئي

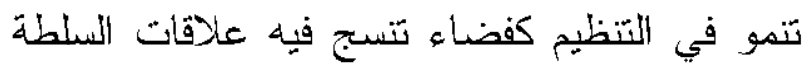
Crozier,Michel and Friedberg,Erhard(1980) ,Actors and systems, Chicago, university of chicago,press, 2 
الانتماءات المتقاطعة"9؛، وهو ما أتت على ذكره

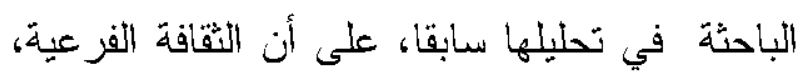

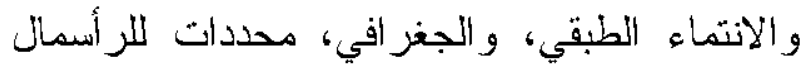

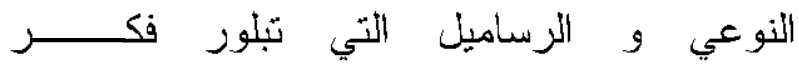

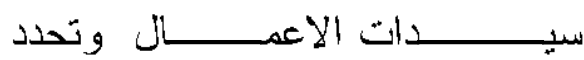




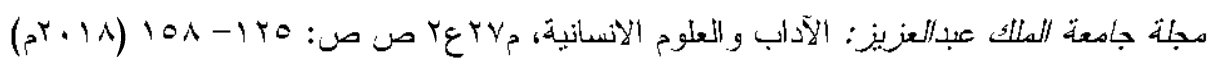
DOI:10.4197/Art.27-2.5

بـــــلات سيدات الاعمال للهوية المهنية

\begin{tabular}{|c|c|c|c|}
\hline كل المعو امل & جغر افية/مـادية & نقافية/اجتماعية فقط & العو امل المركبة للهوية الثخصية \\
\hline 7. & . & . & العدد \\
\hline$\% 1 \ldots$ & $\%$ & $\%$ & النسبة \\
\hline ورية جماعية & هوية جماعية & هوية فردية & تصور سيدات الاعمال للهوية المهنية \\
\hline ry & 10 & $1 \wedge$ & 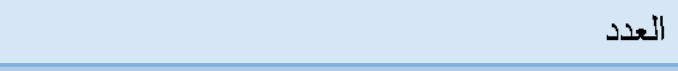 \\
\hline$\%$ so & $\%$ ro & $\%$ & النسبة \\
\hline مسنقلة & 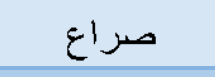 & 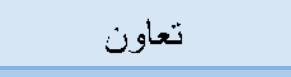 & تمثل سيدات الأعمال لآليات اثتغال الهوية المهنية \\
\hline$\cdot$ & $r \varepsilon$ & YY & 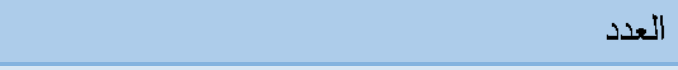 \\
\hline$\%$ & $\%$ ov & $\% \varepsilon r$ & النسبة \\
\hline
\end{tabular}

الفرد، وعن تجارب ابتذائية منصلة به ولها ثلى مفرط مقارنة بالتجارب الناحقة(0). وعلى الرّغم من أن شيكيلة سيدات الاعمال في هذه الدراسة تعبر عن المشروع الحداثي الأي تتوخاه المملكة العربية السعودية في الاندماج الاجنماعي الأي يحترم التتوع و التعدد و الاختلاف، ويو ازن بين المصالح و الخصوصيات المختلفة، في إطار قانوني يؤكد المساواة اللتامة في المواطنة، ويخلو من التمييز على أسس العزق أو الجنس، او المنطقة، أو أي انتماء آخر بحثا عن تتوع منسجم. الا ان الثقافة
توجهاتهن، وهي ذاتها محددات للر أسمال النوعي و الرساميل التي تبلور فكر سيدات الاعمال وتحدد توجهاتهن، وهي ذاتها التي تتحت هوياتهن الشخصية من خلا "الهابيئوس" الذي يسمح لنأفراد بالّتوجه في فضاءهم الاجنماعي، ونبني ممارسات تتفق و انتماءاتهم، و إذا كان الهابيتوس يمنح الفرد امكانية بناء استز اتيجيات استباقية، فإن ذلك لا يمنع هذه الاستز اتيجيات من أن تكون منقادة بتزسيمات لاو اعية، "تزسيمات إدرالك، وفكر، وفعل تثولا عن فعل التزبية و التنشئة الاجتماعية التي يخضع لها

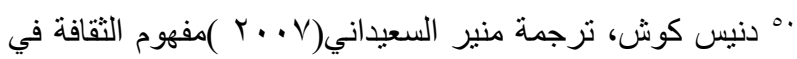

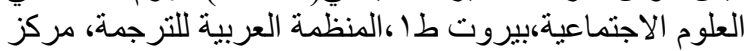

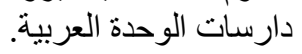


الاحترام ، الاعنبار، والتقدير و الثتة في النفس

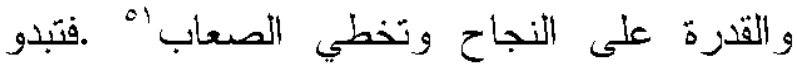
الهوية المهنية بالنسبة اليهن فردية على اعتبار انها تعادل الانا والذات كما يراها الباحث حيدر

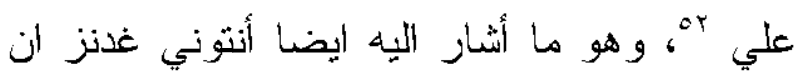
هذه الهوية المهنية تتعلق بتصور الناس وفهمهم لأفسهم ولما يعتقدون انه مهم في حياتهم من اعمال

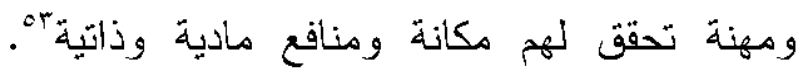

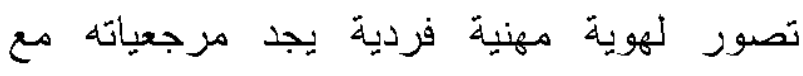

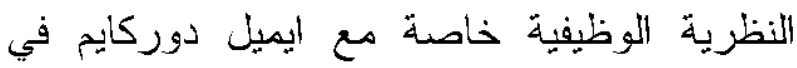
تقسيمه الاجنماعي للعمل في المجتمعات الصناعية الذي يتسم بالتضامن العضوي، و الذي أفرز بدوره فائضا من الفردانية الحديثة نكاد تذرر الاتتماءات الاجنماعية التي كانت تسيطر على المجنمعات

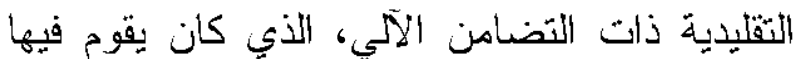

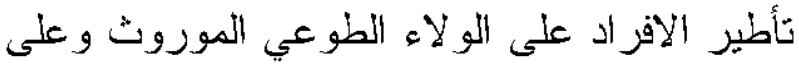

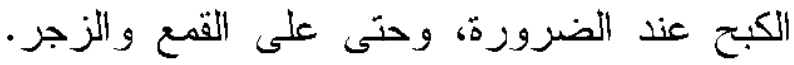

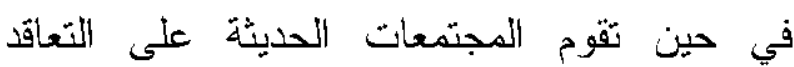
و الانتماء الازرادي؛ بـ بينما تفسر المقاربة النفسية المتتاولة لتكون الهوية المهنية بأنها تطور للهوية الذاتية، والقدرات و الصفات الشخصية التي تعزز الشعور بالأمن النفسي الذي يرتبط بوضوح الهوية

1ا الجراي فتحي ، سوسيولوجيا الخدمة الاجتماعية المهنية في

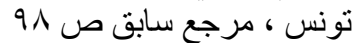

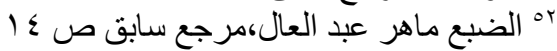

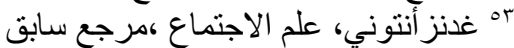

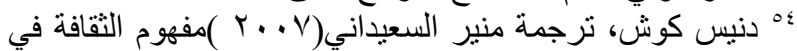

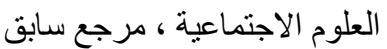

الفرعية و الفضاء المورفولوجي و الانتماء الطبقي من ضمن الأوائز التي يتم فيها بناء الهوية الشخصية لسيدات الاعمال، خاصة وانه قد تمت الإشارة سابقا القى دور اللبنية الذهنية المتغيرة من

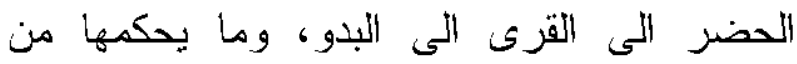
قو الب اجتماعية تفرز صورا لأبعاد تتكرر ووجوه وهاه تثقاطع فيما يتعلق بصورة المرأة وتمثل أدوارها بين البيت والعمل، و هي في الحقيقة تبقى رهينة مشهد اجنماعي وثقافي برسم هندسة لبنية ذهنية تجسم هوية المر أة في مرحلة لاحقة، وهو ما كانت الباحثة قد اقتفت أثزه من خلا نسبة سيدات الاعمال اللاتي حدد انتمائهن اللى فضاءات جغرافية وطبقات اجنماعية مختلفة وعي تام بان هذه الهوية الشخصية هي مركب من هذه العوامل مجتمعة كما جاء في تصريحات سيدات الاعمال نموذج در استنا. تصور اختلفت رؤاه عندما تعلق الامر بالهوية المهنية لسيدات الاعمال ، اذ تعتبر ، بـ\%ن عينة البحث انها هوية مهنية فزدية بامنياز على اعتبار

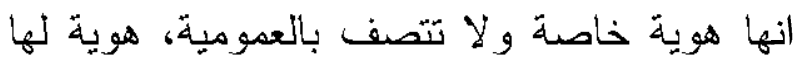
أبعاد ذاتية تحيل إلى تصور سيدة الاعمال لنفسها، او الصورة التي تبنيها عن ذاتها بما يجعلها مغايرة عن غيرها من خلال التمثلات و التصورات التي لاني تجعلها تتسم في الحالة السوية بالاسنمرار النسبي هن والثبات إلى حد ما ، وهي الصورة ذاتها التي تحظى بدرجات مختلفة من الاعتراف الأتي 
المهني ، وهو ما يبزر تمثل سيدات الاعمال للأكان النفسي الذي تحققه لهن الكوية المهنية الجماعية.

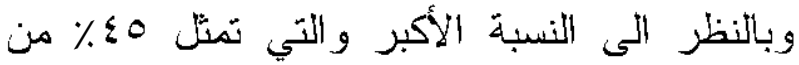
سيدات الاعمال اللاتي تصنفن الهوية المهنية على

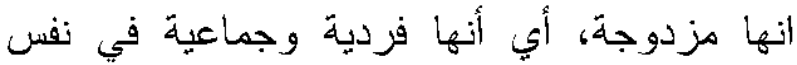

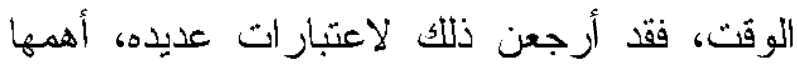

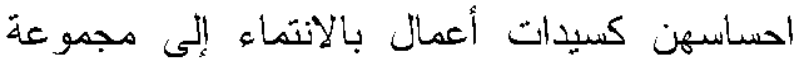
مهنية لها خصوصيتها الطبقية والاجنماعية، حيث يكون التماهي في هذه الحالة منبادلا داخل المجموعة على اعتبار ان الفضاء المهني يقع ضمن هندسة اجتماعية خاصة، و يعترف بالأفزاد الدا من خلا تُعرفهم على ذواتهم داخل النموذج

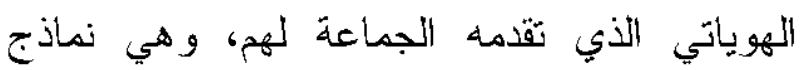
منضدة واقعة في سلم تصنيفات عادة ما تكون معيارية (أي ما ينبغي ان يكون فئية عليه المنتمي

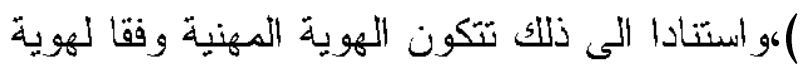
الجماعة ضمن استزاتيجيات داخل المنظومة المهنية، و التي تمت الاشارة اليه دع ميشال كروزييه في تفكيكه لآليات انشتغال التنظيمات التهات و المجموعات المهنية. ان تمثل 0؛ ٪ من سيدات

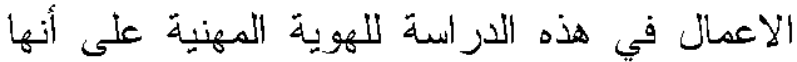
فردية وجماعية في نفس الوقت، يجد له مرجعيات مع التفاعلية الزرمية أيضا خاصة مع بيكار Hughes , Becker المجموعات المهنية الىى مسارين الأول، مسار بيو غر افي تتشكل وفقه الهوية المهنية ضمن سياقات
المهنية؛، وهو ما أشارت اليه نسبة كبيرة من سيدات الاعمال على اعتبار انهن حققن الأمان المهني لتمكنهن من تحقيق شوط كبير في مجالهن العملي رغم بعض الصعوبات و العراقيل التي تو اجهرن كعنصر أنثوي في مجتمع لا تزال فيه

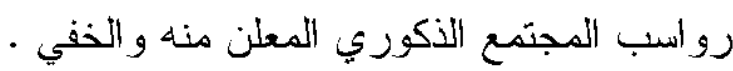
تصور لا تجد الباحثة صداه لاى هب٪ من سيدات

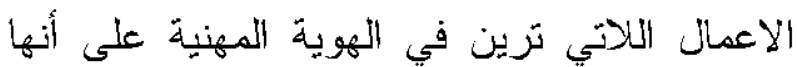
جماعية، على اعنبار انهن إزاء صور و تمثلات تبنيها المجموعات، ولا يمكن ان تكون الا نتاج علاقات مهنية توحد الهوية المهنية وتفترض لترض التماهي مع الآخرين الأين يفرض عليهم الانتماء الىى نفس الحقل او الدجال التماهي دعهم، او على لنى الأقل التشابه في بعض النواحي المهمة .اذا هو تمنل لهوية مهنية جماعية متلبسة داخل منظومة يحددها الاتتماء الىى فضاء عملي واحد، رغم تعدد المجالات والاختصاصات، الا انه يرسم مشهدا موحدا في مجال المال و الاعمال و التوجاهة الاجتماعية، و الرساميل المتتوعة تزداد ترسيخا للوعي بهوية مهنية جماعية، فرضنها طبيعة الفضاء الذي يرسم ملامح مشتركة للمنتمين اليه، لهائ وهي نتاج لعلاقات وتفاعلات، ويكون التماهي الهوياتي في هذه الحالة منبادلا داخل هذا الحقل

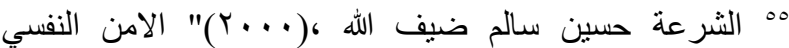

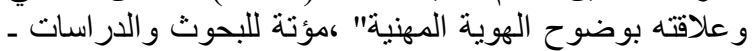

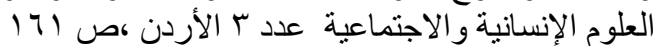


رؤية .ب.r.r، اذ تعتبر فترة ذهبية خاصة بالنسبة

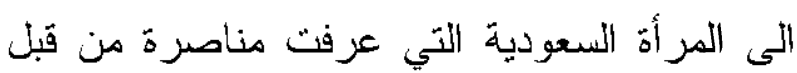
القيادة الرشيدة حيث فتحت لها الباب على على لهرديه مصر اعيه لتلج المر أة السعودية مجالات عديدة كان

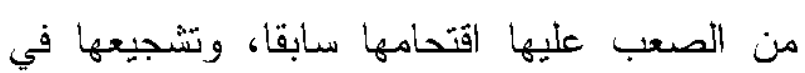
مجال ريادة الاعمال و التميز فيه. نجاح تعبر عنه سيدات الاعمال بان له ضريبيته،

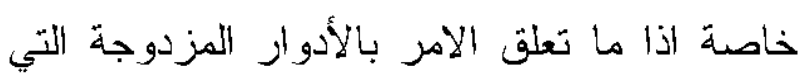
تقوم بها المر أة السعودية داخل بيتها ومع أسرتها، وضرورة نجاحها في عملها، وهو ما يتطلب منها

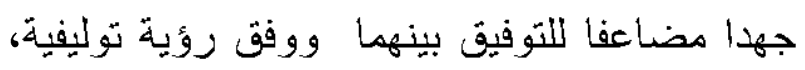
وهنا تتحدث سيدات لأعمال عن التعاون الذي لوني تجدنه من طرف العائلة و الززوج لإنجاح مسيرتهن المهنية والاسرية، تعاون هن في حاجة اليه داخل الفضاء المهني أيضا، ويعبر عن شبكة علائقية

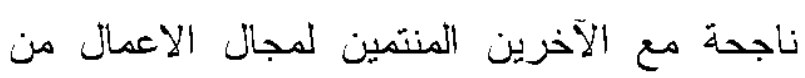

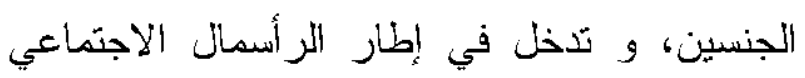
الذي تكونه سيدة الاعمال إلى جانب الرساميل التي في

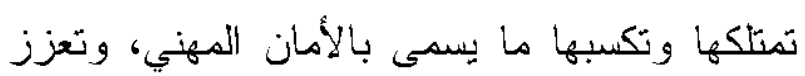

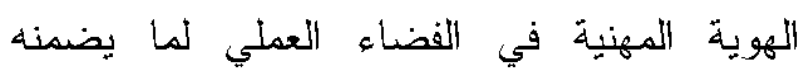

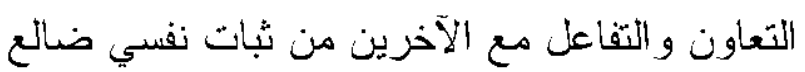

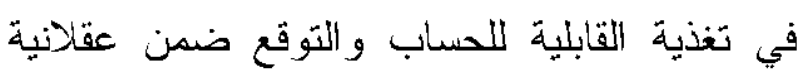
و استر اتيجية اقتصاديةله تقوم على منطق المصالح و التبادل ،تتحدث عنها سيدات الاعمال على اعتباز انها تضمن تحقيق أرباح ومنافع ذاتية، و مادية،
فردية أو عائلية وخبرات وتجارب ذاتية .و الثاني مسار التفاعل أبي جملة الأنشطة التبادلية الناشئة

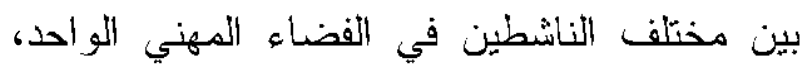

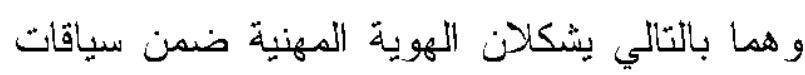

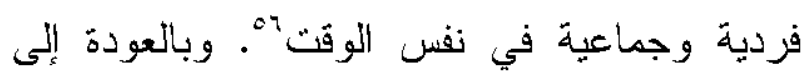
تمثل سيدات الاعمال لآليات اشتخال الهوية المهنية

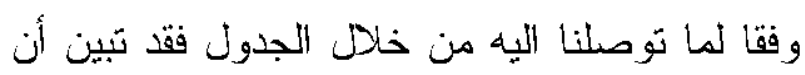
بـ من سيدات الاعمال تزى أن النعاون آلية

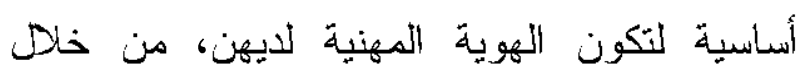
الإحساس بالانتماء الى فضاء مرموق اجتماعيا،

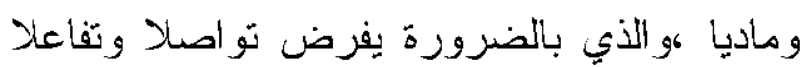

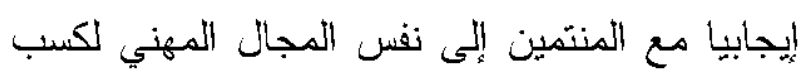

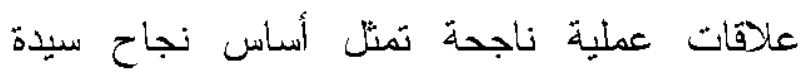

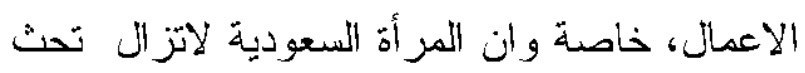

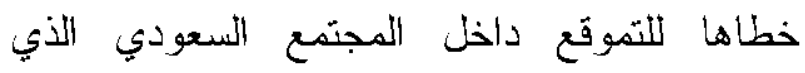

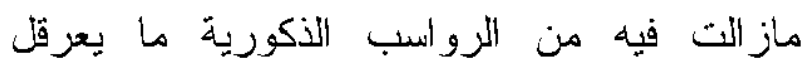

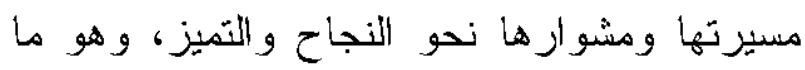

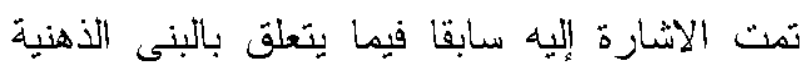

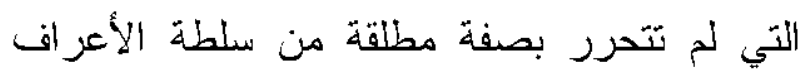

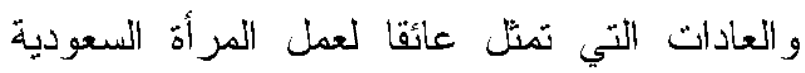
لاسيما في المجالات التي تعرف بأنها ذكورية بامتياز. غير أن التشريعات وسياسة المملكة التي لاتي

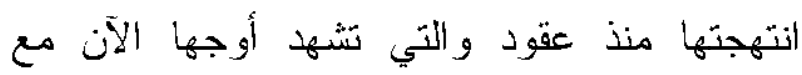
الإصلاحات الر ائدة للملك سلمان وولي العهد محمد لهدئ

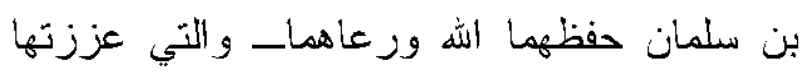


وأسلوب تعامل مغاير للنمط التقليدي بين الرجل و المر أة في المجال المهني، وما من شك في أن هذاير

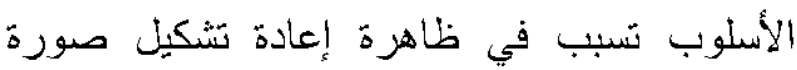
مغايرة للصورة النمطية عن المرأة وأدوارها، فالمر أة أصبحت عنصرا فاعلا في كل المجالات بعد أن كانت عالة على المجتمع، وهو ما أكسبها قيمة رمزية وحظوة لدى الزجل، و ساعد على تعميق علاقاتها الاجتماعبة و العملية بعد أن كانت سطحية، وهو تغير كامن أساسا في النسق الاجتماعي، وارتفاع المستوى التقافي و التنعليمي للمرأة، و استقلالها الاقتصادي، الذي أكسبها هيبة واعية في إطار العلاقات المكرو مو الميكروسوسيولوجية. التي قد تخلق بدروها صراعات من أجل التموقع وتحقيق أهدافها داخل الفضاء المهني. صراعات تحدثت عنها نسبة كبيرة من سيدات الاعمال على اعتبار ان اقتحامهن لمجال ريادة

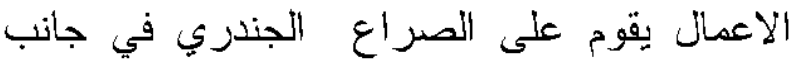
منه، بالإضافة الىى صراع الرساميل منها ما هو مادي، و اجتماعي، وثقافي، ورمزي، تتشكل وفقها هوية مهنية ضمن منطق العقلانية التجارية التي تستثر في المال والعلاقات بين الافراد المنتمين اللى نفس الفضاء المهني، وهو ما ذهب اليه "آلان

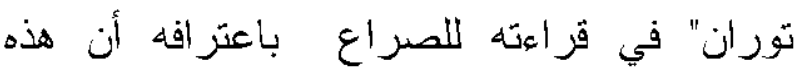

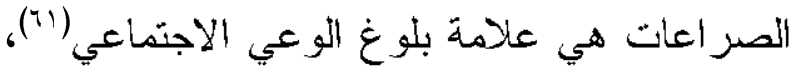

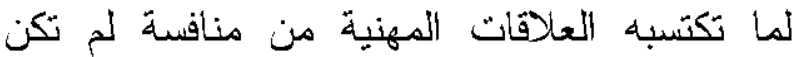
مطروحة في السابق، بل هي نتيجة لحياة

"“ أنصار بيار، العلوم الاجتماعية المعاصرة، ، مرجع سابق
رغم وجود المنافسة في الفضاء و الأي قد يتحول الى صراع حسب ما نزاه أكثر من نصف عينة

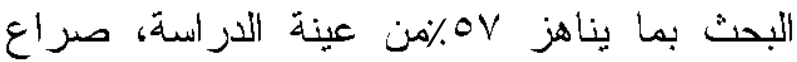
يمثل آلية من آليات أشتغال الهوية المهنية داخل حقل الاعمال على اعتبار انه فضاء يتسم بالذكورية، كرؤية مركزية للنظام الاجنماعي الذي يشتغل باعنباره آلّة رمزية هائلة تصبو إلى هرتي

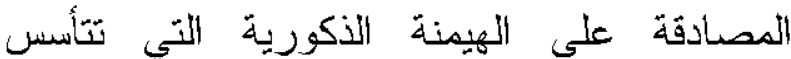
عليها( (०)

صراع يجد له جذور في التحليل الماركسي، أ لم يتحدث عنه كارل ماركس Karl Marx باعنباز

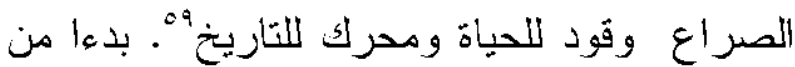
الصراع من اجل البقاء، وصولا الى الصراع الطبقي، و صراع الجندر، الأبي يؤكد على عدم

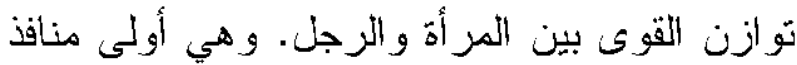
الصراع التي تتحدث عنها سيدات الاعمال وفقا تهات لمقاربة جندرية تجد تفسيرا لها فيما أشار الإيه بورديو في مجال تحليله لبنية العلاقات بين الجنسين، "إن الأشكال التي ينتظم وفقها النظام الاجتماعي التقليدي تؤدي إلى تصنيف كل الأشياء وكل" السلوكات وفق التعارض النوعي بين الجنسين"(י). وبما أن المهنة والأجر يكسبان الشخص مكانة و هيبة، نلمس أفعالا سلوكية جديدة

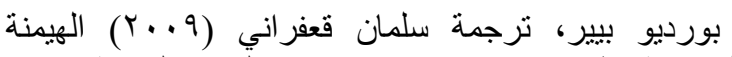

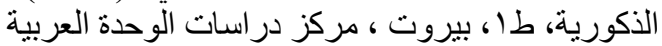

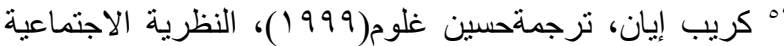
من برسونز إلى هابرماس، طا ، الكويت، سلسلة عالم المعرفة، المجلس الوطني للثقافة و الفنون و الآداب. " بورديو بيير، الهيمنة الذكورية، مرجع سابق الآلق 
ومناطق جغز افية مختلفة ،وهو ما يعبر عن قدرة

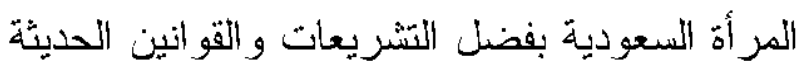
و التي أتاحت لها فرض ذاتها وتعزيز ثقتها بنفسها، ومواجهة كل الصعوبات للنجاح وخوض غمار ونار ريادة الاعمال الذي يتطلب توفر رساميل نوعية

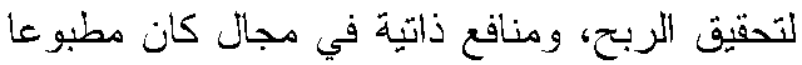

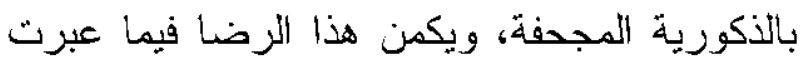
عنه النسبة الأكبر من سيدات الاعمال في تحقبقهن للأمان المهني، والوصول التى تحقيق هوية مهنية

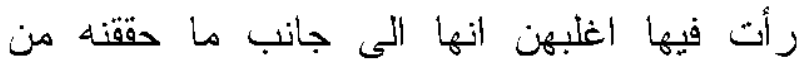
أرباح مادية، فقد اكتسبن مكانة اجتماعية مرموقة

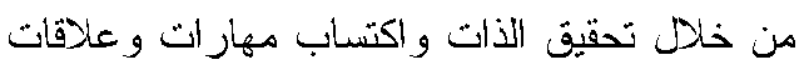
اجتماعية، وهو ما نتج عنه إحساسهن بالارنباح

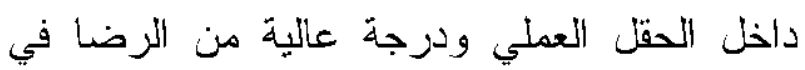

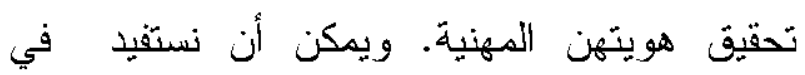
تحليل هذا الرضا من لنمن الرضن

نظرية ماسلو Maslow حول مفاهيم هرمية الحاجات، وربطها بجو انب مختلفة من حياة الافراد

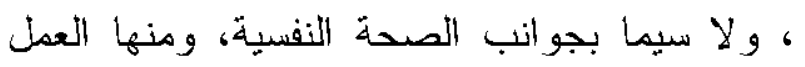
وتحقيق الذات كحاجة ملحة للتوازن النفسي، و اشباع حاجة الفرد للتموقع داخل المجتمع واثبات ذاته من خلال الذور الذي يقوم به، والأققييم الإيجابي لنفسه الذي يحصل للفرد من خلا لهل تقييم

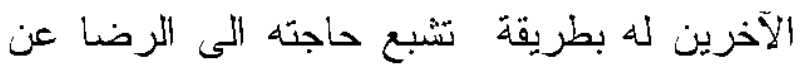

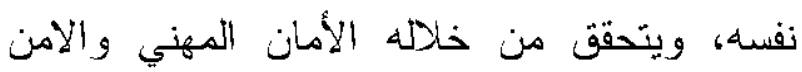

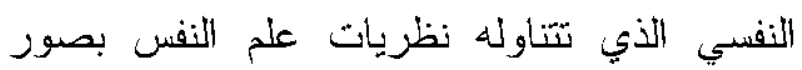

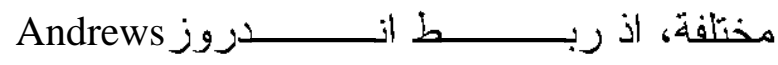

المجتمعات الحديثة، وتطور وضعية المرأة و عقليتها، وهنا ترتسم دينامية اجتماعية وعملية جديدة تفترض دخول المرأة لعالم الاعمال منطقا بر اغماتيا يقوم على العقلانية التجارية، ومنطق استثماري في تشكيل علاقات تفاعلية توظف فيها

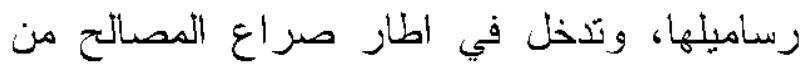

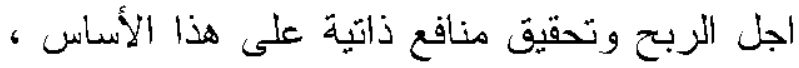

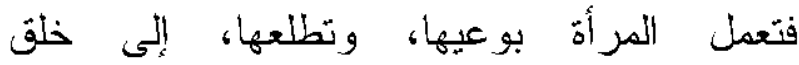
استر اتيجيات تجعلها منحفزه للافاع عن مصالحها توظف فيها كل رساميلها وعلاقاتها و العقلانية الاسنثمارية استزاتيجيات تحدث عنها "ميشال كروزيه" بإسهاب، بأنها تذخل في الطار إدارة

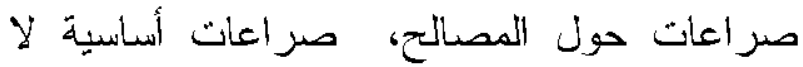
تقتصر فيها علاقات النفوذ على علاقات السيطرة

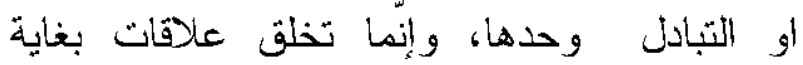
التزابط تُنىى من خلا مختلف الصر اعات داخل والثل

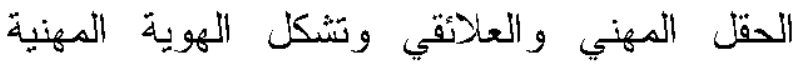
للأفراد ،وهو ما سعت مدرسة التفاعلية الرمزية الىى اثباته في مقاربتها للحقل المهني، ان المهنيين

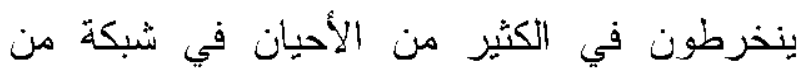

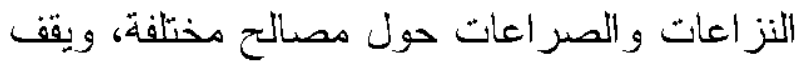
ور اء ذللك عو امل موضو عية و أخرى ذاتية.

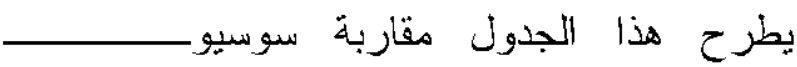
ثقافية تمكن الباحثة من تفكيك المعطيات التي مني توصلت اليها أهمها: ارتفاع نسبة سيدات الاعمال في عينة الار اسة و الالاتي عبرن عن تحقيق الرضا المهني، و اعتزاز هن بهويتهن المهنية بنسبة لVV على اختلاف انتماءاتهن التى طبقات اجتماعية، 
مفهوم الامن النفسي بالإشباع الذاتي الناتج عن

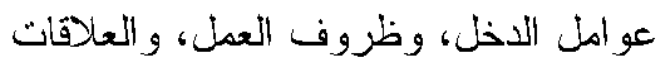

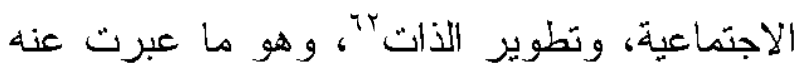

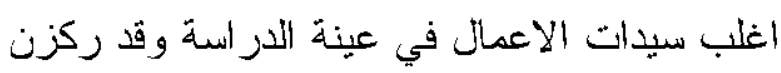




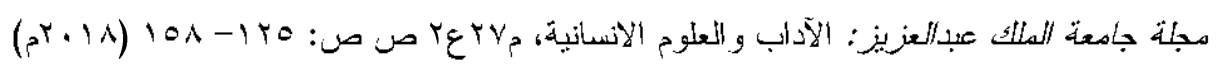

DOI:10.4197/Art.27-2.5

عـــالهوية المهنية لاى سيدات الأعمال بين المر افققة والمفارقة

\begin{tabular}{|c|c|c|c|}
\hline ضتعيف & منو سط & عالّي & الرضا عن تحقيق هوية مهنية \\
\hline . & $1 \leq$ & $\leqslant 7$ & 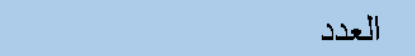 \\
\hline$\%$ & $\%$ Yr & $\% V V$ & النسبة \\
\hline
\end{tabular}

الفزص الاستثمارية المتاحة أمام النساء الر اغبات في اقتحام مجال ريادة الاعمال.

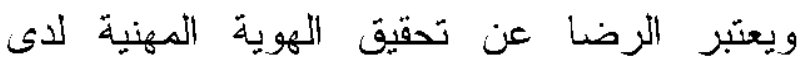
سيدات الاعمال ناجم عن شعورهن بالقدرة على

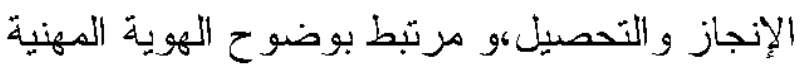

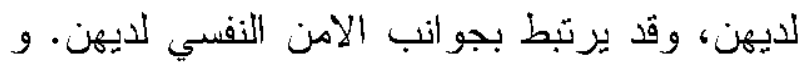
يذهب اسبو osipow إلى أن وضوح الهوية المهنية

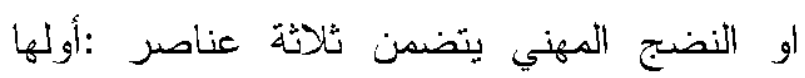

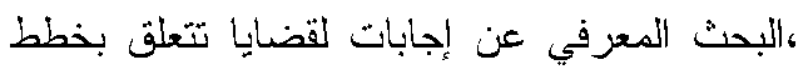
الفرد المهنية وثانيها، امتلاكك معلومات كافية حول الفابك

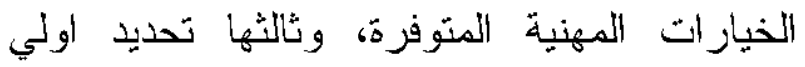
للتوجهات المهنية، أي تضييق الفرد لخياراته المهنية. ولوضوح الهوية المهنية تأثير على حياة

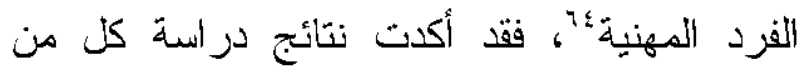

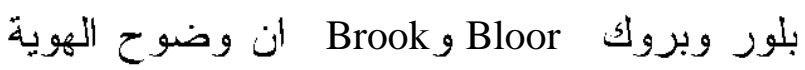
المهنية يرتبط إيجابيا بالقدرة على اتخاذ القرار

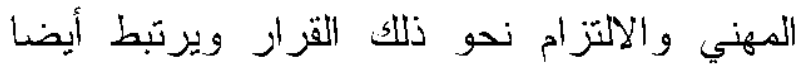

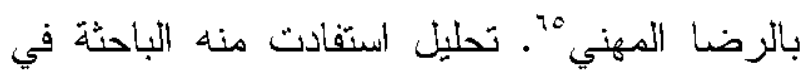

${ }^{64}$ Of career development ,published by prentice Hall college e Osipow,H(1983), theories

${ }^{65}$ Bloor,D,and Brook,J(1993),"Career Development of Students Pursuing Higher education, journal of education studies vol 285 p57
على طبيعة العمل و دور الغرف التجارية و الصناعية في توطيد شبكة العلاقات مع المنتمين الىى نفس المجال وما تقدمه خاصة في أقَسامها النسائية المستحدثة، من خدمات عديدة ومنتوعة اللمنتسبات، مثل الخدمات القانونية وخدمات التتريب و التأهيل، وخدمات البحوث و الأراسات

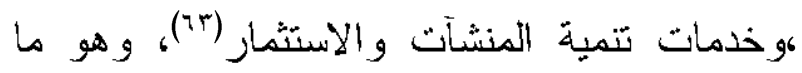

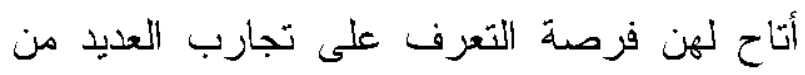
المنتمين لنفس الفضاء المهني والانفتاح على ريادة لرعاد الاعمال، وهو ما يعتبرنه مكسبا رمزيا و اعتز افا

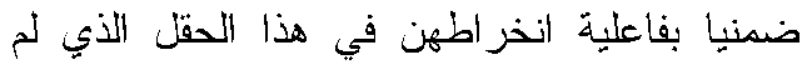

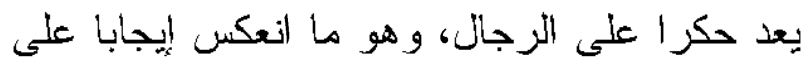

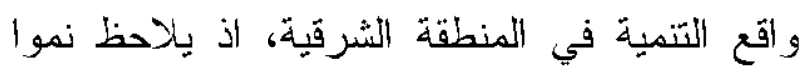
في حجم الاستثمارات النسائية، ويعود ذلك إلى الى لئه

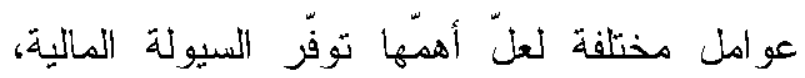

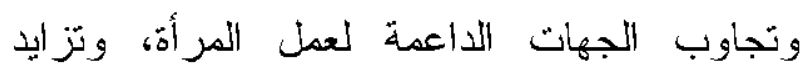

rآ ـ ورقة اعمل أعدنها الإدارة العامة لمجلس الغرف النسائية

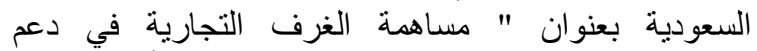
الاستثمارات النسائية، قدمت في ملثنقى المرائة الخيليجية

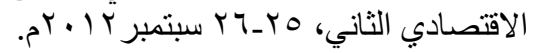


ورمزي اقوى و المنتمين لطبقة اجتماعية أرقى، و التي تفسر الناتتاظر بين المنتمين لنفس الفضاء

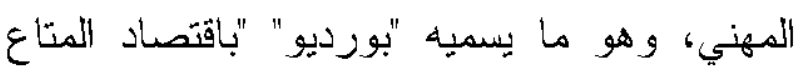

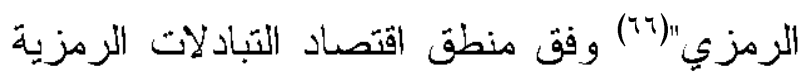

داخل الحقل المهني.

• نتائج البحث

لا شك في أن المر أة السعودية حققت نجاحات في كل المجالات بفضل السياسة التي انتهجتها المملكة

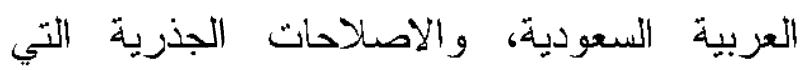

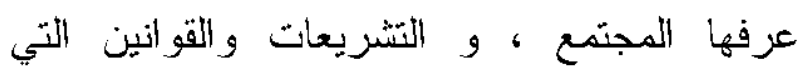
اعطت دفعة قوية ونفسا حداثيا في كل المجالات

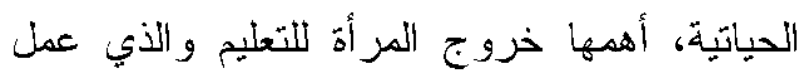

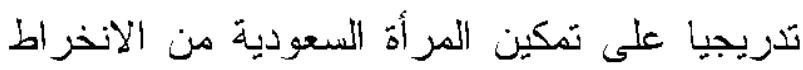
في سوق العمل رغم المعوقات الاجتماعية و التقافية التي عرقلت اقتحامها لمجالات مهنية اعتبرت ذكورية بامنياز، غير أن ما تشهده المملكة العربية

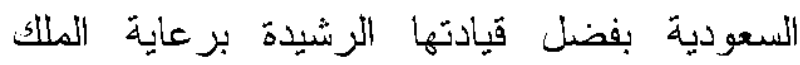

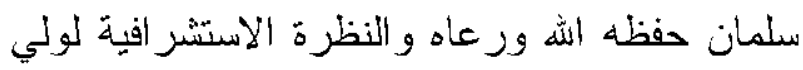
العهد محمد بن سلمان رائد القفزة الحداثية حفظه الله وسدد خطاه ووفقا لرؤية .r.r.r و التي مكنت المرأة من حقوق كثيرة مثل قيادة السيارة ،وفتح آفاق العمل في مجال السياحة والاعلام، عزز هيرة

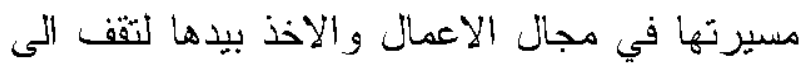
جانب الرجل للنهوض بالمجتمع وجعله في مصاف لهاف

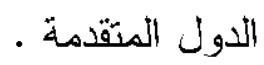

"י" بورديو بيير، الهيمنة الذكورية، مرجع سابق.
فهم آليات اشتخال العلاقة الطردية بين الرضا عن تحقيق الهوية المهنية الذي تحس بـ سيدات الاعمال في عينة الدراسة و الوضوح المهني، على اعتبار انه بحقق لهن امنيازات مادية، ومركز اجنماعي، وعلاقات مهنية و اجتماعية، بما هو انشباع لحاجتهن

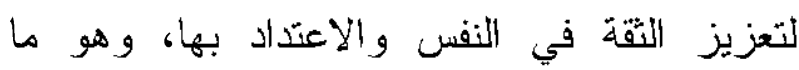
عبرت عنه نسبة كبيرة من سيدات الاعمال في هذا البحث عن درجة الرضا العالي في تحقيق هذه الهوية المهنية وتقدير الذات. توجه تقل درجته لاى بr \%من اجمالي سيدات الاعمال المعنيات بهذه الار اسة و الالاتي عبرن عن لهن رضاهن المتوسط في تحقيق هوية مهنية، لاعتبار ات أهمها ما يصطدمن به داخل الفضاء العملي من صعوبات في التمكن من التموقع داخل بل دهن مجال الاعمال و إرساء علاقات قوية مع المنتمين لنفس الفضاء، باعتباز انه بحتوي بدوره على تمايز

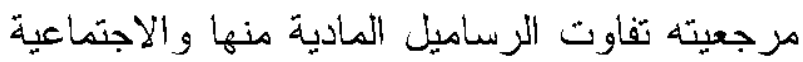

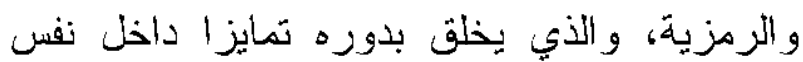

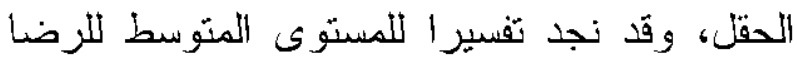
عن تحقيق هوية مهنية في حاجتهن الى تطويز

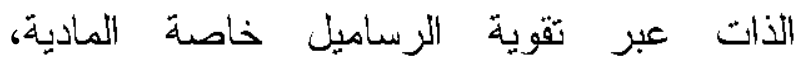
والاجتماعية، لضمان شبكة علائقية تضمن لهن لهن استثمار هذه الرساميل التي تعتبر طاقات تولد مز ابيا مادية ورمزية وتمثل "خطوط تماس غيبية" تحدثت عنها فرجينيا وولف، على أنه يمثل طقسا رمزيا

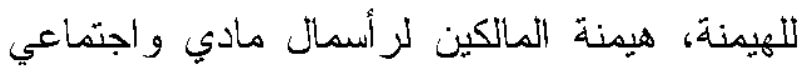


مداخل ملائمة لتفسير ما عبرت عنه نسبة كبيرة من عينة الار اسة في تمثلهن للهوية المهنية داخل حقل ريادة الاعمال، الذي يشترط وجوبا رأسمال يحدد التموقع داخل هذا الفضاء، وصر اعا من اجل لنئل النمايز واثبات الأات من اجل النجاح وتحقيق

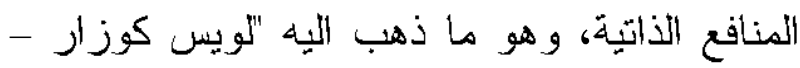
"Lewis Goser

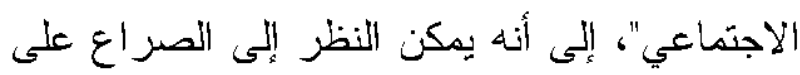

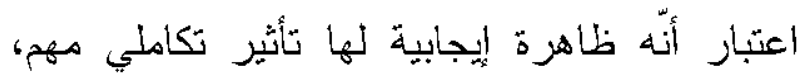
فمن خلا الصراع بطلق النسق شحنات التونز الكامنة فيه، ويدخل سلسلة من التعديلات في آليات عطه، ويسير هذا التحليل على نفس خطى تحليل

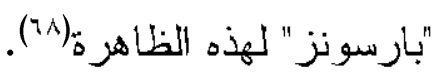

هنا تجد الباحثة نفسها مدفوعة بالمقاربة السوسيولوجيه الىى قراءة تنضيدات اجتماعية

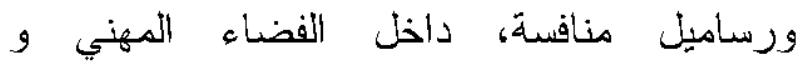
الاجتماعي، تتحدد وفقها الهوية المهنية التي لتئية تكنسبها سيدة الاعمال و تمثلها لعو امل تشكل هذه

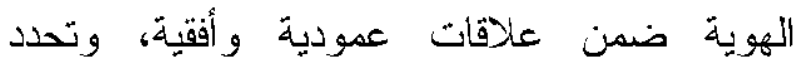
موقعها ضمن شبكة علائقية او ما يسمى بالز أسمال

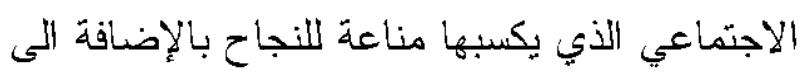

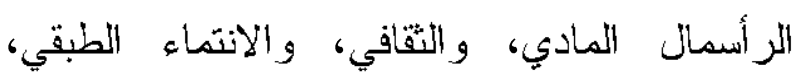
و التي تمثل رساميل نوعية متفاوتة حسب الافراد وادي

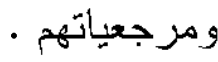

نتائج توصلت اليها الباحثة من خلال هذه الدراسة ضمن قز اءة سوسيولوجية لعينة من سيدات الاعمال

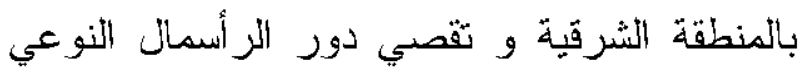

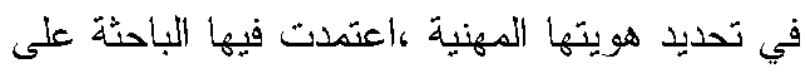

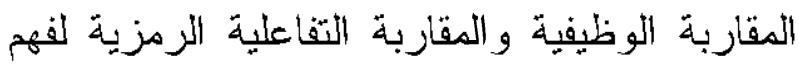

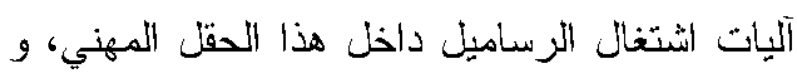
هنا يجب الإقرار بفضل سنسوليو فيما امد به البحث من أدوات علمية لفهم آليات اشتخال الهوية لهاية

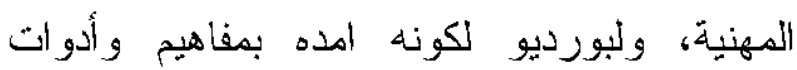
نظرية، استفادت منها في حدود ما تسمح به إثكالية

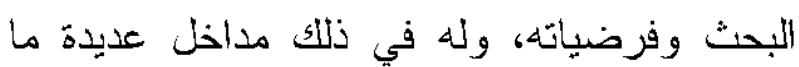

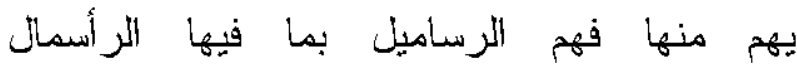
الاجتماعي، التقافي، المادي و الرمزي ودورها في لهامي تحديد الهوية المهنية لسيدات الاعمال. رساميل

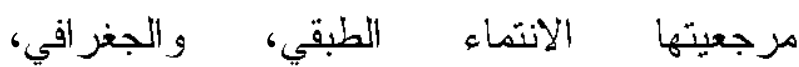
و الاجنماعي، والثقافي كوالتي تشكل تمايزا بين المنتمين الكى نفس الحقل المهني ضمن مستويات

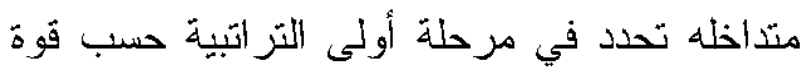
الر أسمال الأي تمنلكه سيدة الاعمال، وفي مرحلة ثانية تحدد الهوية المهنية في حقل يدلو بمنطقه

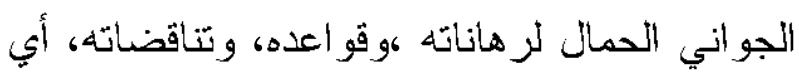
بين الهابيتوس و الثروط الاجتماعية التي تشكل هذه

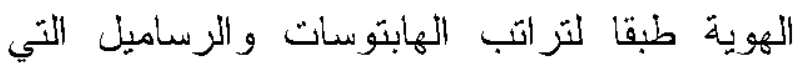
تمتلكها سيدة الاعمال في بنية الحقل أو في البنية

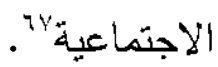

^^كريب إيان، ترجمةحسين غلوم(1999)، النظرية الاجتماعية من برسونز إلى هابر ماس، ترجرجع سابق
V" بورديو بيير ، جان كلود باسرون ، إعادة الإنتاج ، مرجع سابق 
اذا ييدو المشهد العام لتمثل سيدات الاعمال تجاربهن وتعزيز قدر اتهن لتوظيفها في تجاوز كل السعوديات للهوية المهنية، مشهدا حافلا بتنضيدات المعوقات. وتعبيز ات دلالية تقرأ من خلالها الباحثة قدرة ـ مزيد التزكيز على دور المؤسسات والمنظمات

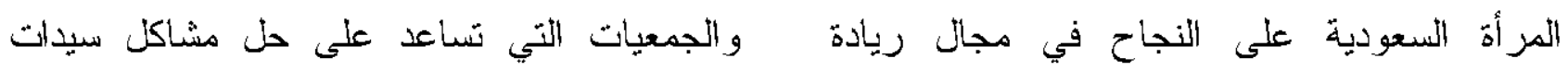
الاعمال، والذي كان يتميز بذكورية هيمينه على الاعمال ليتحقق لهن المستوى الأعلى من الامن فئل

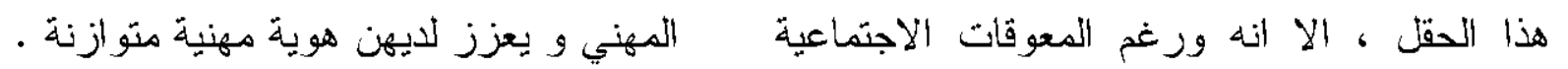
و الثقافية التي لاز الت المرأة تصطلم بها الا أنها ـ تعزيز الرساميل المادية و الثقافية والاجتماعية استطاعت بفضل مثابرتها وتعليمها وبفضل التي تحمها سيدات الاعمال من خلا التدريب

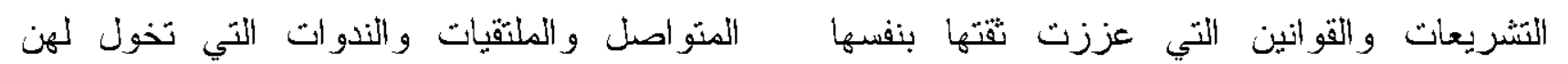
ومكنتها من اقتحام ميادين الععل معتزة بهويتها توسيع شبكة العلاقات الداخلية والخارجية، لتعزيز قدراتهن وخبراتهن المهنية في مجال الاعمال وتضمن تجاوزهن لكل ما يعيق هسار النجاح و التموقع داخل هذا الفضاء العملي. المراجع العربية المفاء العمية

ـ اجلا إسماعيل،حلمي (1999) العنف الأسري، مصر ، دار قباء

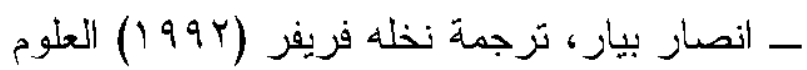
الاجنماعية المعاصرة ،الطبعة الاولى، بيروت،

$$
\text { المركز الثقافي العربي }
$$

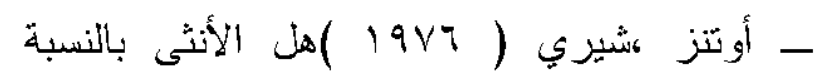

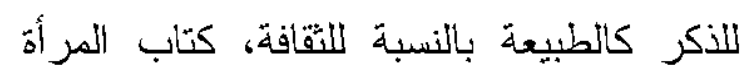

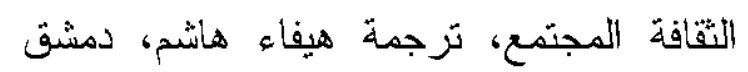
وزارة الثقافة

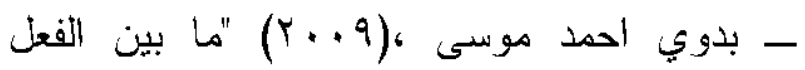
و البناء الاجتماعي : بحث في نظرية الممارسه

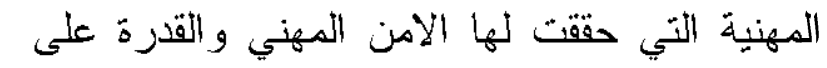
مواجهة التحديات وكل ما من شأنه أن يعيق

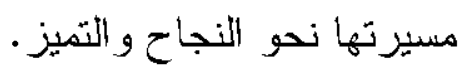
• توصبات الباحثة لقد توصلت الباحثة من خلا هذه الدراسة حول دور الرأسمال النوعي في تحديد الهوية المهنية

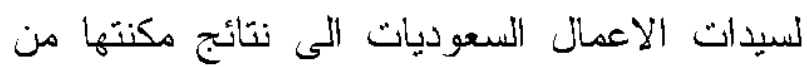
الخروج بالتوصيات التالية : ـ ضرورة مواصلة دعم سيدات الاعمال خاصة منهن المبتدئات في مجال ريادة الاعمال بما تحتاجه هذه الفئة من دعم وتأطير لتجاوز كل ما يعيقها من من فئن

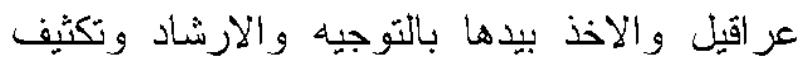
الذورات التكريبية لتوضيح خارطة الطريق التي ولتي تخول لها النجاح و الوصول إلى أهدافها.

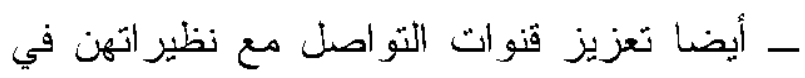

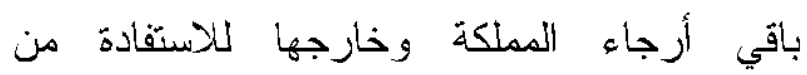


ـ التغيرات المجتمعية و تأثير ها على وظائف

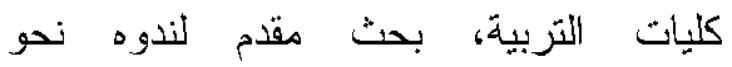
استزراتيجية مستقبليه لإعداد المعلمين

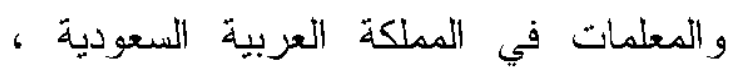
جامعه الملك سعود، كليه التزبية، البك اه

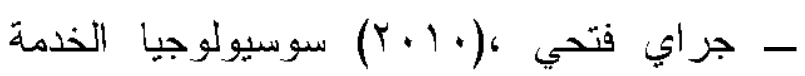

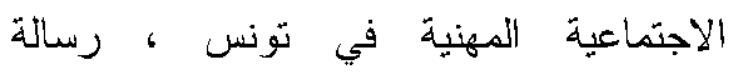
دكتوراه، كلية العلوم الإنسانية والاجتماعية تونس

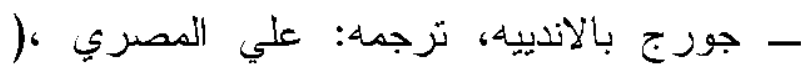
(Y.IV الثانية، بيزوت، المؤسسه الجامعيه للار اسات و النشر

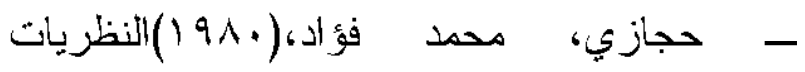

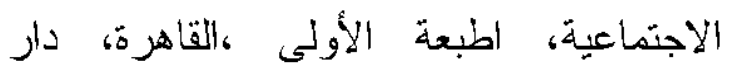

$$
\text { غريب للطباعة }
$$

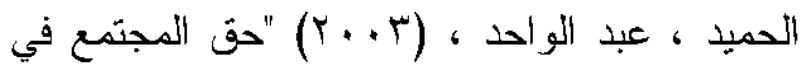

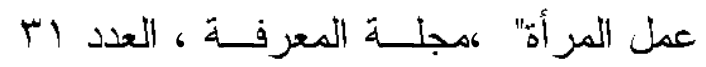

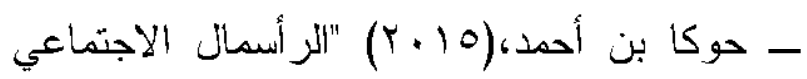
ورابطة العيش المشترك :دراسة في الركائز

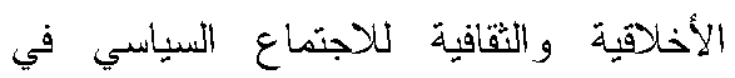

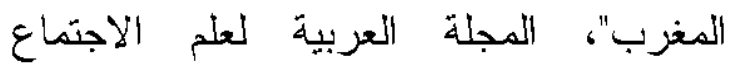
(إضافات) (العدد · ب لبنان

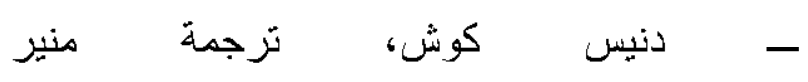

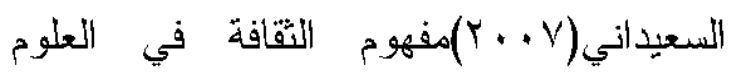

لأى بيير بورديو" المجلة العربية لعلم الاجنماع إضافات مجلا ^ ، ل لبنان

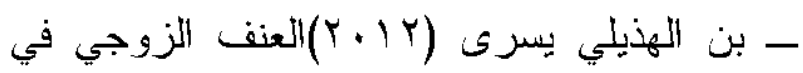

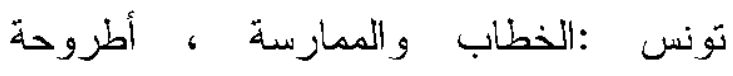
دكتوراه في علم الاجنماع ، كلية العلوم الإنسانية و الاجتماعبة بتونس

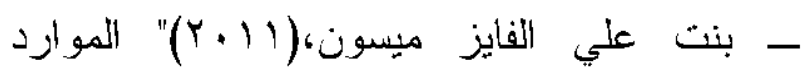
البشريه النسائية السعودية : : نحو الطار استراتيجي لرؤية مستقبليه للتمكين"، مجلة دراسات في الخدمه الاجنماعيه و العلوم لرونيه

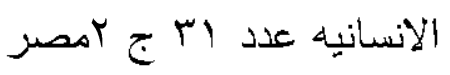

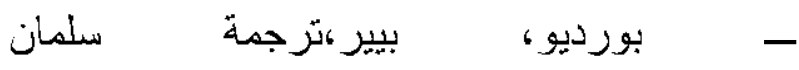

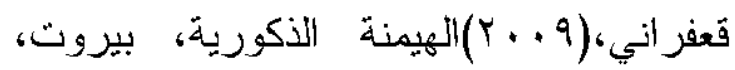
مركز دراسات الوحدة العربية المنظمة العربية للتزجمة مرحر دران

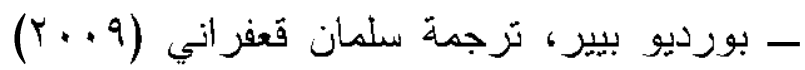

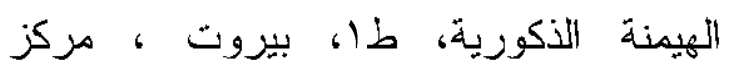
در اسات الوحدة العربية - بورديو بيير، تزجمة عبد السلام بن عبد العاللي (19人7)،

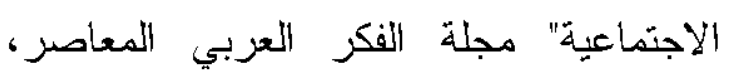
مركز الانماء بيروت،العددباع مجله - بورديو، بيير، جون كلود باسرون ،ترجمة ماهر الهردير

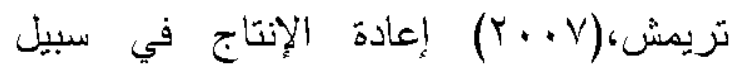

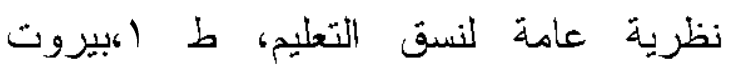

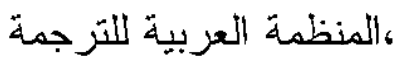




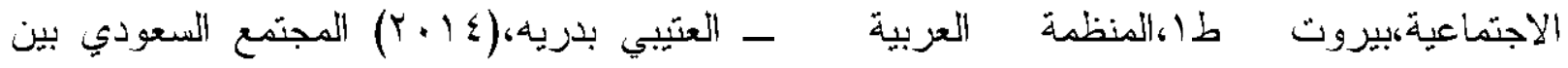

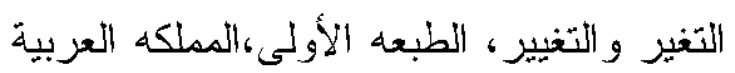
للتزجمة، مركز دارسات الوحدة العربية السعوديه، مكتبة ناشرون

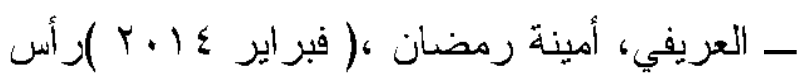

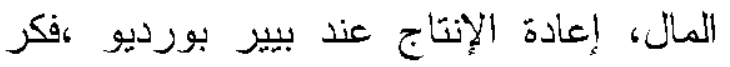

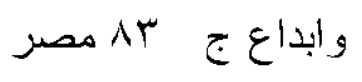

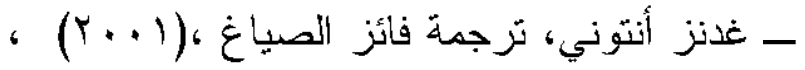

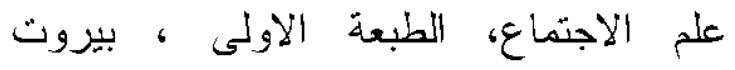
، المنظمة العربية للترجمة التهاعة

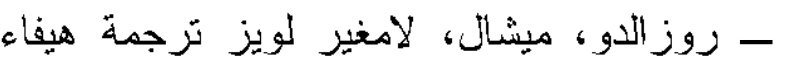

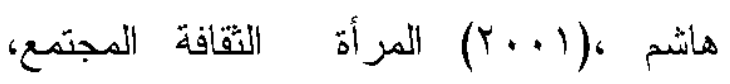
كمشثق، وز ارة الأقافة. - ريمون بودون، يوريكو، تزجمة سليم حداد

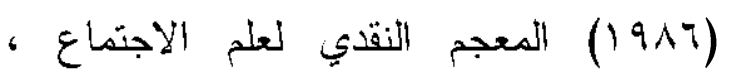
بيزوت ،المؤسسة الجامعية للار اسات و النشر و التوزيع - غيث ، محمد عاطف و ل آخرون ، (199V)، الإسكندرية ، دار المعرفة الجامعية

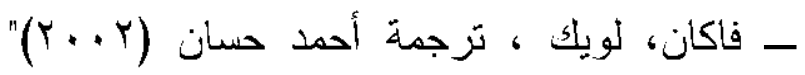
نحو علم ممارسة اجنماعي: بنية سوسيولوجيا بورديو ومنطقها" ، مجلة فصول العدد

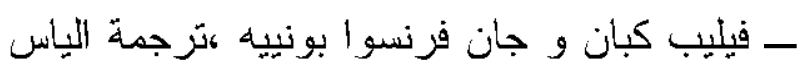
حسن(· (ب)،علم الاجتماع من النظريات

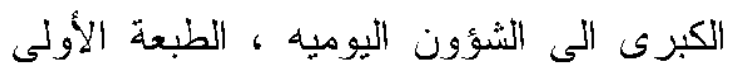

$$
\text { دمشق، دار القرقان }
$$

- كريب إيان، ترجمةحسين غلوم(999 (1)،

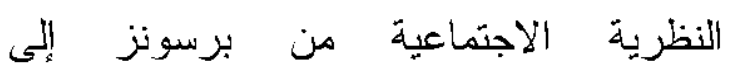
هابرماس،طا ،الكويث، سلسلة عالم المعرفة، المجلس الوطني للانقافة و الفنون و الآداب

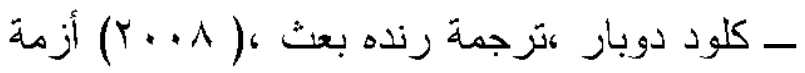

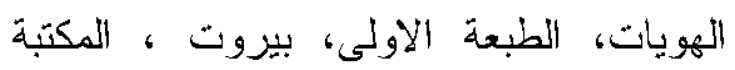

ـ - شرابي ، هشام،(1991)، مقدمات لار اسة المجنمع العربي، بيزوت ،الطبعة ع ،دار الطليعة للطباعة و النشر النر

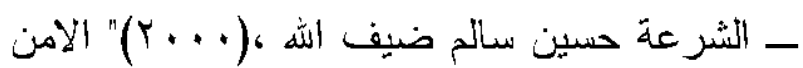
النفسي و علاقته بوضوح الهوية المهنية" ،مؤتة للبحوث و الدراسات - العلوم الإنسانية و الاجتماعية عدد ب الأردن ـ الضبع ماهر عبد العال ،(10 + ب)،"ملامح الهوية الهن لدى أبناء المصريين المولودين في مجتمعات غربية:دراسة ميدانية بمدينة فيينا النمساوية" لمولين المجلة العربية لعلم الاجتماع (عددهام) مركز

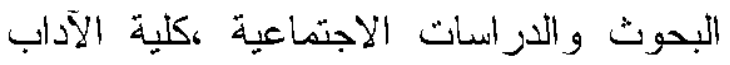

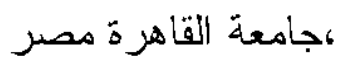

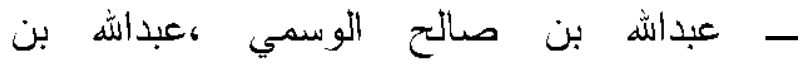

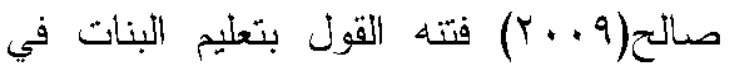
المملكة العربية السعودية، بيروت المركز

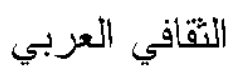


ـ مجموعة من المؤلفين (0. . . م) تحية إلى روح هشام شرابي ، ط اتونس ،المجمع التونسي

للعلوم و الآداب و الفنون بيت الحكمة

ـ منتصر أمال،(1999)" التحو لات في العلاقات

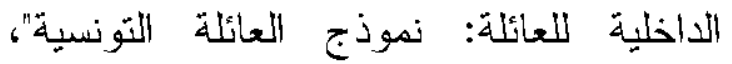

المجلّة التونسية للعلوم الاجثماعية، عدد 11 11

- وزارة الاقتصاد والتخطيط، تقزيز الاقتصاد

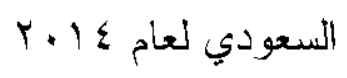

ألمر اجيع الاجنبيه

-Bloor,D ,and Brook,J(1993),"Career Development of Students Pursuing Higher education, journal of education studies

-Castel, Manuel(2004),the power of identity,2 edition London

-Crozier ,Michel and Friedberg ,Erhard(1980) ,Actors and systems Chicago, university of chicago,press, 2

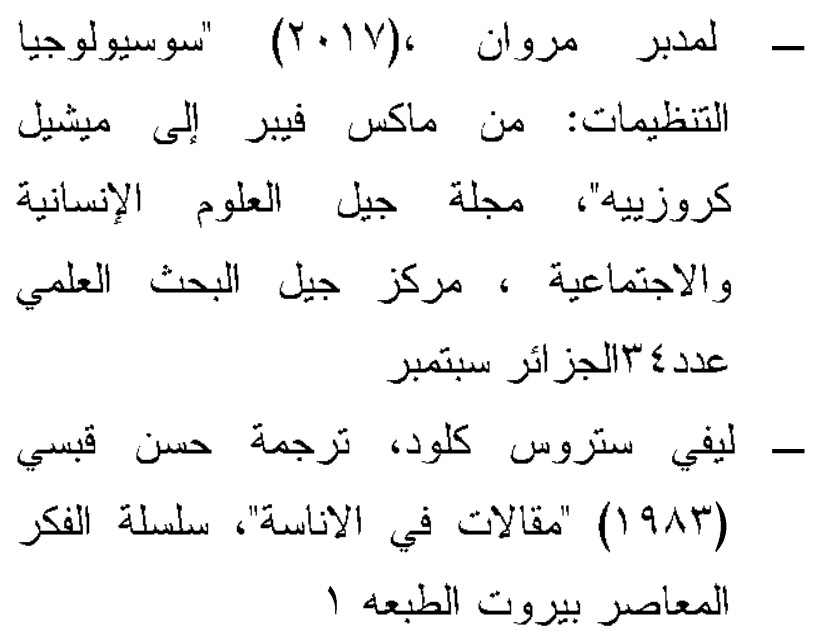

- Osipow ,H(1983),theories Of career development ,published by prentice Hall college

-Putnam ,Robert,(1993)Making Democracy Work ,Princeton , university press

-Putnam ,Robert "Bowling (1995)Alone .America's Declining Social Capital "journal of democracy vol.6, p62)

-Simmel, George (1976) The Stranger The Sociology of Georg Simmel New York: Free Pres 


\title{
The role of qualitative capital in the professional identification of Saudi women Businesswomen in the Eastern Region model
}

\author{
Dr.Kholoud AlThaqafi \\ King Faisal Uneversity
}

\begin{abstract}
The modernist landscape of the Kingdom of Saudi Arabia makes us look at the mechanisms of the modern Saudi society, which has been engaged in development paths and a developed vision to invest all its human and economic energy .Women have formed a vital part of these energies, having strengthened her position and rights through legislations and laws, that have made her an effective force, whose impact has affected the Saudi economy in various fields. The international community has recognized the potential and success of Saudi women in the Kingdom. Therefore, this study came as an attempt to reveal the reality of women's energies within the professional fields that were previously male only.But the changes Saudi Arabia has undergone for decades have made women succeed in many areas, such as entrepreneurship.

In this study, we examine the ability of Saudi women to succeed in this professional space through their ability to prove their professional identity, as well as the role of qualitative capital (economic, social, cultural and symbolic) in defining this professional identity of businesswomen in the Eastern Province of Saudi Arabia as a study case.
\end{abstract}


